\title{
Integration of Digital Economy and Circular Economy: Current Status and Future Directions
}

\author{
Zhen Liu ${ }^{1, * \mathbb{D}}$, Jing Liu ${ }^{1, *}$ and Mohamed Osmani ${ }^{2}$ \\ 1 School of Design, South China University of Technology, Guangzhou 510006, China \\ 2 School of Architecture, Building and Civil Engineering, Loughborough University, \\ Loughborough LE11 3TU, UK; m.osmani@lboro.ac.uk \\ * Correspondence: liuzjames@scut.edu.cn (Z.L.); 201921052597@mail.scut.edu.cn (J.L.)
}

Citation: Liu, Z.; Liu, J.; Osmani, M. Integration of Digital Economy and Circular Economy: Current Status and Future Directions. Sustainability 2021, 13, 7217. https://doi.org/ $10.3390 /$ su13137217

Academic Editor: Antonella Petrillo

Received: 4 May 2021

Accepted: 24 June 2021

Published: 28 June 2021

Publisher's Note: MDPI stays neutral with regard to jurisdictional claims in published maps and institutional affiliations.

Copyright: (c) 2021 by the authors. Licensee MDPI, Basel, Switzerland. This article is an open access article distributed under the terms and conditions of the Creative Commons Attribution (CC BY) license (https:// creativecommons.org/licenses/by/ $4.0 /)$.

\begin{abstract}
Circular economy (CE) is a concept actively advocated by the European Union (EU), China, Japan, and the United Kingdom. At present, CE is considered to grant the most traction for companies to achieve sustainable development. However, CE is still rarely adopted by enterprises. As the backbone of the fourth industrial revolution, the digital economy (DE) is considered to have a disruptive effect. Studies have shown that digital technology has great potential in promoting the development of CE. Especially during the COVID-19 epidemic that has severely negatively affected the global economy, environment, and society, CE and DE are receiving high attention from policy makers, practitioners, and scholars around the world. However, the integration of CE and digital technology is a small and rapidly developing research field that is still in its infancy. Although there is a large amount of research in the fields of $\mathrm{CE}$ and DE, respectively, there are few studies that look into integrating these two fields. Therefore, the purpose of this paper is to explore the research progress and trends of the integration of $\mathrm{CE}$ and DE, and provide an overview for future research. This paper adopts a bibliometric research method, employs the Web of Science database as its literature source, and uses VOSviewer visual software to carry out keyword co-occurrence analysis, which focuses on publication trends, journal sources, keyword visualization, multidisciplinary areas, life cycle stages, and application fields.
\end{abstract}

Keywords: circular economy (CE); digital economy (DE); multidisciplinary; application field; life cycle stage; keyword co-occurrence; keyword visualization

\section{Introduction}

The origin of the term "circular economy (CE)" is still controversial [1]. Greyson [2] claims that Kenneth Boulding [3] was the founder of the term, whilst Liu et al. [4] and Yuan et al. [5] stress that it was originally a Chinese concept. Pearce and Turner [6] believe that the term "CE" first appeared in Western literature in the 1980s. Although the term "CE" is associated with various meanings, it usually has a common concept, which is a circular closed-loop system [1].

At present, CE is a concept advocated by the European Union (EU), China, Japan, the United Kingdom (UK), and companies around the world [7]. The Ellen MacArthur Foundation [8] indicates that the application of the CE principle can increase the European Gross Domestic Product (GDP) by $11 \%$, with a net benefit of approximately $€ 1.8$ trillion by 2030 , and can save material costs up to USD 1 trillion $[9,10]$. CE is also considered to grant the most traction for companies to achieve sustainable development $[11,12]$, which can be realized by innovative $C E$ business models and responsible consumers [13]. However, there are challenges for CE adoption; for example, the operational risk is transferred to the enterprise [14], and when the user no longer owns the products, the enterprise may have to bear more maintenance costs [15,16] and may also lose part of the user [17]. In addition, because the products in CE are designed to be used for a long time, they may not be able to respond to technological improvements, thus hindering the process 
of enterprise sustainability improvement $[18,19]$. Therefore, the CE model is still rarely adopted by enterprises [20]. CE contrasts with the linear economy, in which products are predominantly manufactured from primary raw materials, sold to consumers, and then disposed of as waste after use [8]. As such, a CE model focuses on the optimization of end-of-life products and assets by reducing, alternatively reusing, recycling, and recovering materials in the production, distribution, and consumption process [13], whilst CE can be a means of linear model regeneration in consumption and production [21]. CE is a global economic model of recovery and regeneration through design, designed to maintain the maximum efficiency and value of products, components, and materials at any time, and reduction of the consumption of limited resources [22].

Recently, the new digital technologies that are the backbone of the fourth industrial revolution are considered to have disruptive effects, such as the Internet of Things (IoT), 3-D printing, big data and related analysis, virtual reality (VR), and augmented reality (AR) [23]. The main source of the digitization process is computerization, which began with commercial mainframe computers in the 1960s [24]. With the arrival of personal computers from the mid-1980s, digital design tools and computerized manufacturing became more mature [25]. Meanwhile, with the rise of digital information and communication technologies (ICTs), and the decline in costs, the popularity of portable computers and communications, global positioning, and the Internet have all been promoted, of which the Internet has become the core of the digital economy (DE) [24]. The technologies and platforms that underpin DE offer great hope for improving the productivity and global connectivity of consumers, workers, enterprises, and peripheral industries, and provide powerful new tools for accelerating innovation in peripheral regions [24]. Therefore, DE is based on a new type of digital ICTs, digitized knowledge, and Internet-related information [26], which covers and changes all areas of industrial and social life in the world economy [27].

Moreover, digital technology can promote $\mathrm{CE}$ in enterprises [9,28-30]. For example, IoT enables companies to remotely monitor the use, status, and location of products in real time [31], to track materials through IoT technology [32], and to recycle scrap products [29], which helps transition to $\mathrm{CE}$ [33]. Based on the use of the results of process analysis and massive data processing in DE, digital data can significantly improve the efficiency of storage, sales, and the delivery of economic activities in various industries, technologies, equipments, products, and services [34]. The sudden outbreak of COVID-19 led to the stagnation of social and economic activities and severely traumatized the global economy [35]. DE has been seen as an important driver in supporting economic growth, including the development of new models and industries, such as online education, telemedicne, and telecommution, and in accelerating the digital transformation of traditional enterprises [36]. At the same time, the process of the United Nations Sustainable Development Goals (SDGs) affected by the epidemic has been severely hampered, with Naidoo and Fisher reporting that two-thirds of the 169 targets will not be met by 2030 [37]. In fact, CE is an important means to promote sustainable development [38].

Furthermore, with digital transformation and increasing demand for sustainability, CE needs to employ more new skills to promote development [39]. At present, studies have shown that digital technology has great potential in promoting the development of $C E[9,28,29,33]$. However, the integration of $C E$ and digital technology is a small and rapidly developing research field, which is still in its infancy [29]. Although there is a large amount of research in the fields of $\mathrm{CE}$ and $\mathrm{DE}$, respectively, there are few studies that look into integrating these two fields. Therefore, the purpose of this paper is to explore the research progress and trends of the integration of $\mathrm{CE}$ and $\mathrm{DE}$, and provide an overview for future research. 


\section{Research Methods}

The research method used in this article is a bibliometric method, which obtains related publications from the Web of Science (WoS) database, and then imports them into VOSviewer for keyword visualization analysis.

Bibliometric maps are a quantitative method that can visualize bibliometric factors of various scientific publications in different network forms, and can also be used to describe the structure and development process of different fields [40]. The data used in this paper are from the core collection of WoS, and the retrieval topic is "circular economy" AND "digital economy" (CE \& DE), and uses VOSviewer literature bibliometric software for keyword co-occurrence research. VOSviewer is a free JAVA-based software developed in 2009 by van Eck and Waltman [41] of the Centre for Science and Technology Studies (CSTS) at Leiden University in the Netherlands, focusing on the visualization of literature data. The keywords co-occurrence method has been applied in different fields such as medical care [42,43], social participation of the elderly [44], and disaster response [45]. The keywords help to focus and refine the core perspectives and topics of the literature in the research area [46,47], and can reflect research hot spots and trends as well [48]. Hence, this paper uses VOSviewer visualization software for keyword co-occurrence analysis to explore the relationship between $\mathrm{CE}$ and $\mathrm{DE}$.

The structure of the research method, which is shown in Figure 1, encompasses five stages: (1) determining the subject of the study, retrieving CE and DE articles, collecting and organizing relevant data; (2) using bar charts and pie charts to record sources of $\mathrm{CE}$ and $\mathrm{DE}$ publications; (3) performing keyword co-existing analysis through VOSviewer, including network visualization, high-frequency keywords, overlays visualization, and hot research keywords; (4) performing multidisciplinary research, according to the classification of "research areas" in the WoS database via selecting subject areas and conducting keyword co-existing analysis; (5) carrying out analysis on life cycle stages and application areas in $\mathrm{CE}$ and DE.

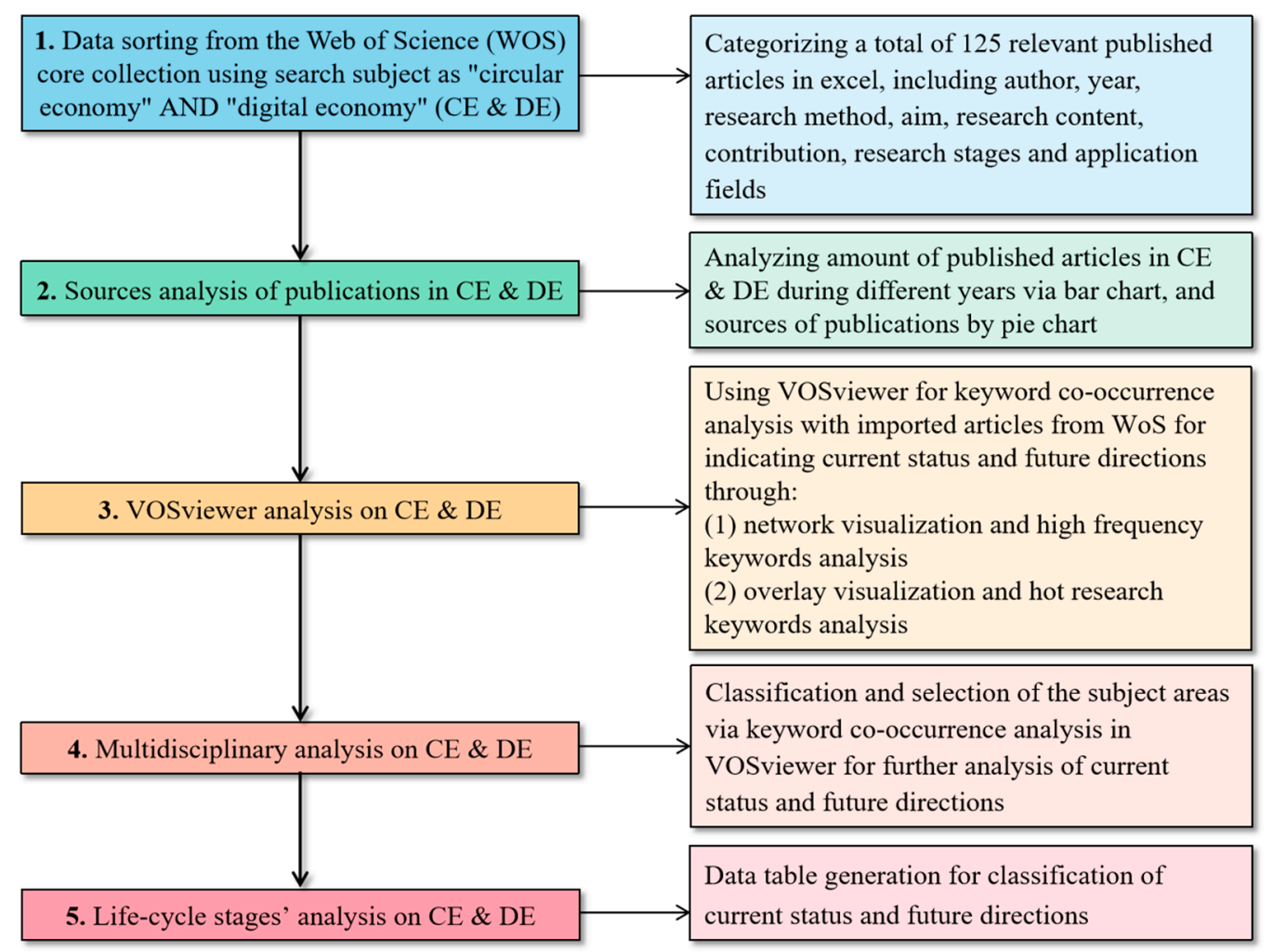

Figure 1. Structure diagram of the research methodology. 


\section{Results}

The data used in this paper are from the core collection of WoS. The retrieval topic is "circular economy" AND "digital economy" (CE \& DE), excluding one irrelevant article from 1998, and displaying a total of 125 search results from year 2016 to 2020.

3.1. Number of Publications and Sources of Publications in "Circular Economy" AND "Digital Economy" (CE and DE)

As shown in Figure 2, the number of articles under the topic of CE \& DE has been increasing year by year from four articles in 2016 to 55 articles in 2020, and it is predicted that this trend will also develop in the future. The sources of publications in CE \& DE are shown in Figure 3, of which the minimum number of publication records is two, and the leading source among 15 sources is SUSTAINABILITY with $33 \%$ of all the published articles, followed by JORNAL OF CLEANER PRODUCTION (13\%), RESOURCES CONSERVATION AND RECYCLING (11\%), PROCEDIA CIRP (8\%), and SCIENCE OF THE TOTAL ENVIRONMENT (5\%).

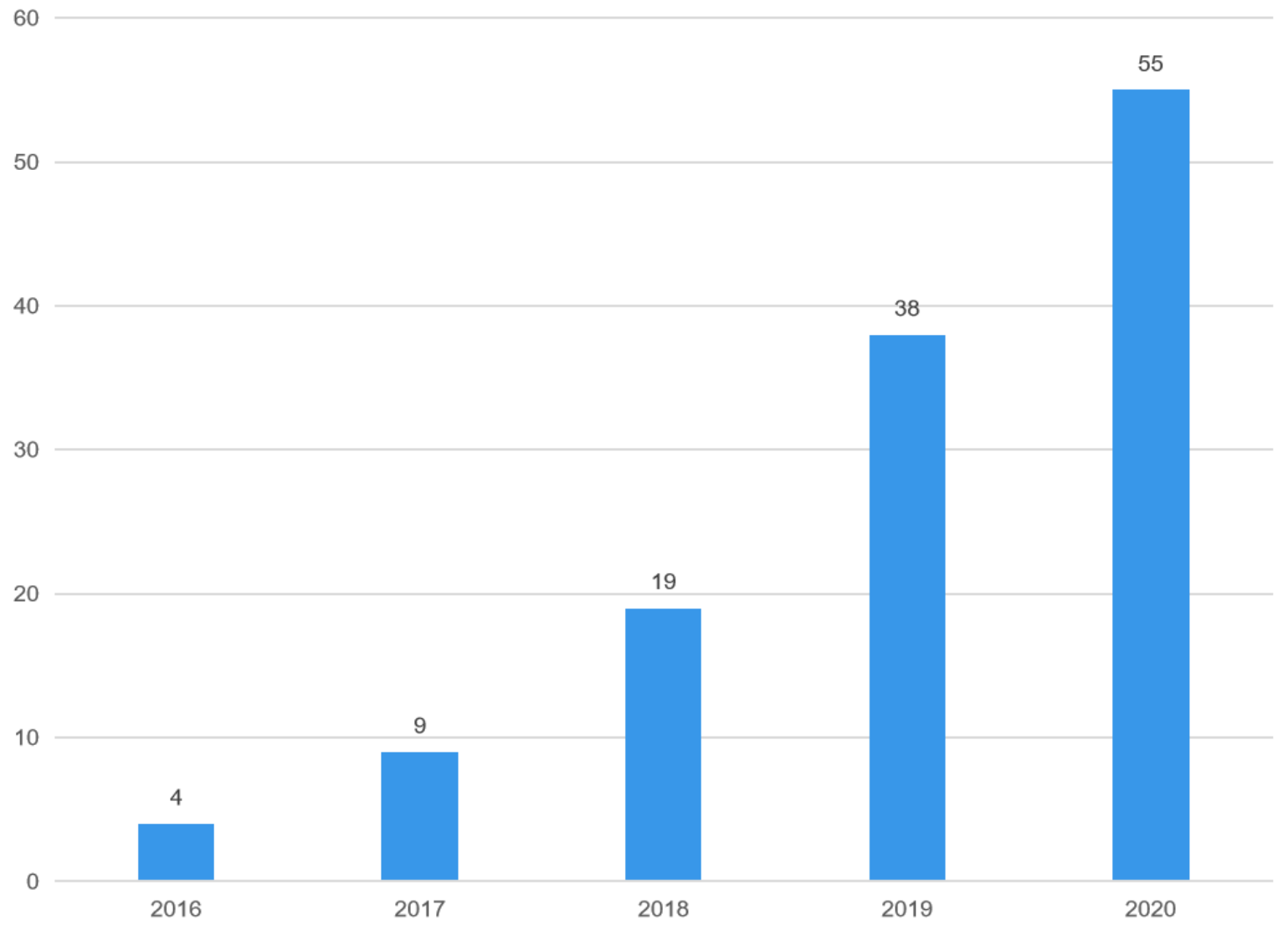

Figure 2. Number of articles published in each year of the "circular economy" AND "digital economy" (CE \& DE) from year 2016 to 2020 in Web of Science (WoS). 


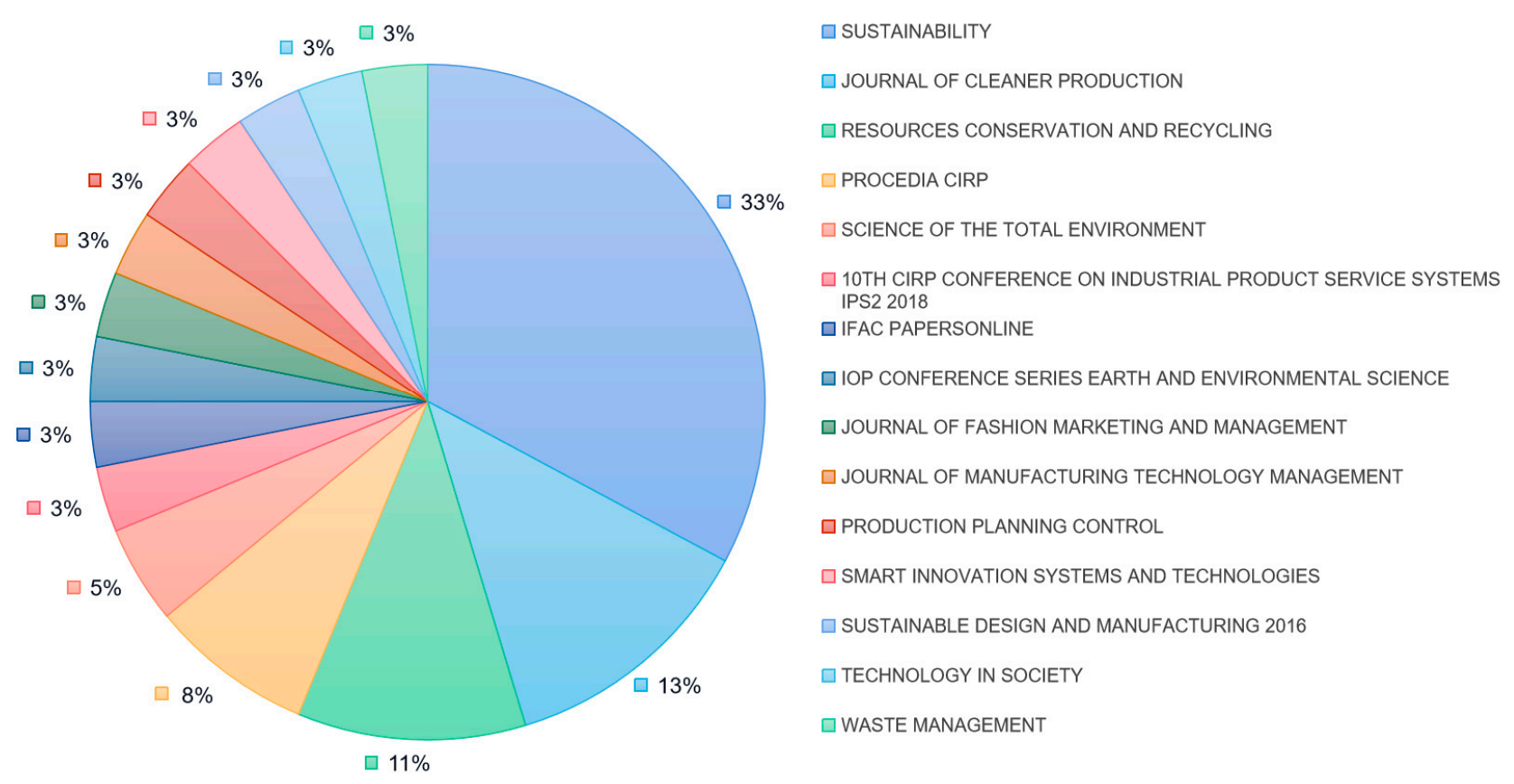

Figure 3. Sources of CE \& DE publications from year 2016 to 2020 in WoS.

\subsection{VOSviewer Analysis on $C E$ and $D E$}

The first step was to import all articles into the software VOSviewer (version 1.6.15) to generate a term diagram of co-clustering for keyword co-occurrence analysis. A total of 609 keywords were used, of which the minimum number of keyword occurrence is two times, and 135 keywords meet the threshold, which are displayed using network visualization and overlay visualization.

\subsubsection{Network Visualization}

In network visualization, there are text labels, circles, connections, and color areas. By default, items are represented by labels and circles. The size of the item label and circle determines the weight of the item, and the position distance or (and) connection strength between the two items represents the strength of their affinity [49]. At the same time, different color regions represent different clusters. As shown in Figure 4, all terms are divided into six different color areas generated from the VOSviewer, representing six different types of clusters. Cluster 1 is mainly related to business, including business mode, servitization, digitalization, value co-creation, and consumer. Cluster 2 is associated with technology, such as digital technologies, IoT, smart manufacturing, AR, and VR. Cluster 3 mainly includes industrial symbiosis and sharing economy, as well as innovation and framework. Cluster 4 is focused on sustainability, with its strategy, supply chain management, and model. Cluster 5 is correlated to management in economic and technical aspects. Cluster 6 is aimed at life cycle management via design, recycling, and waste management. 


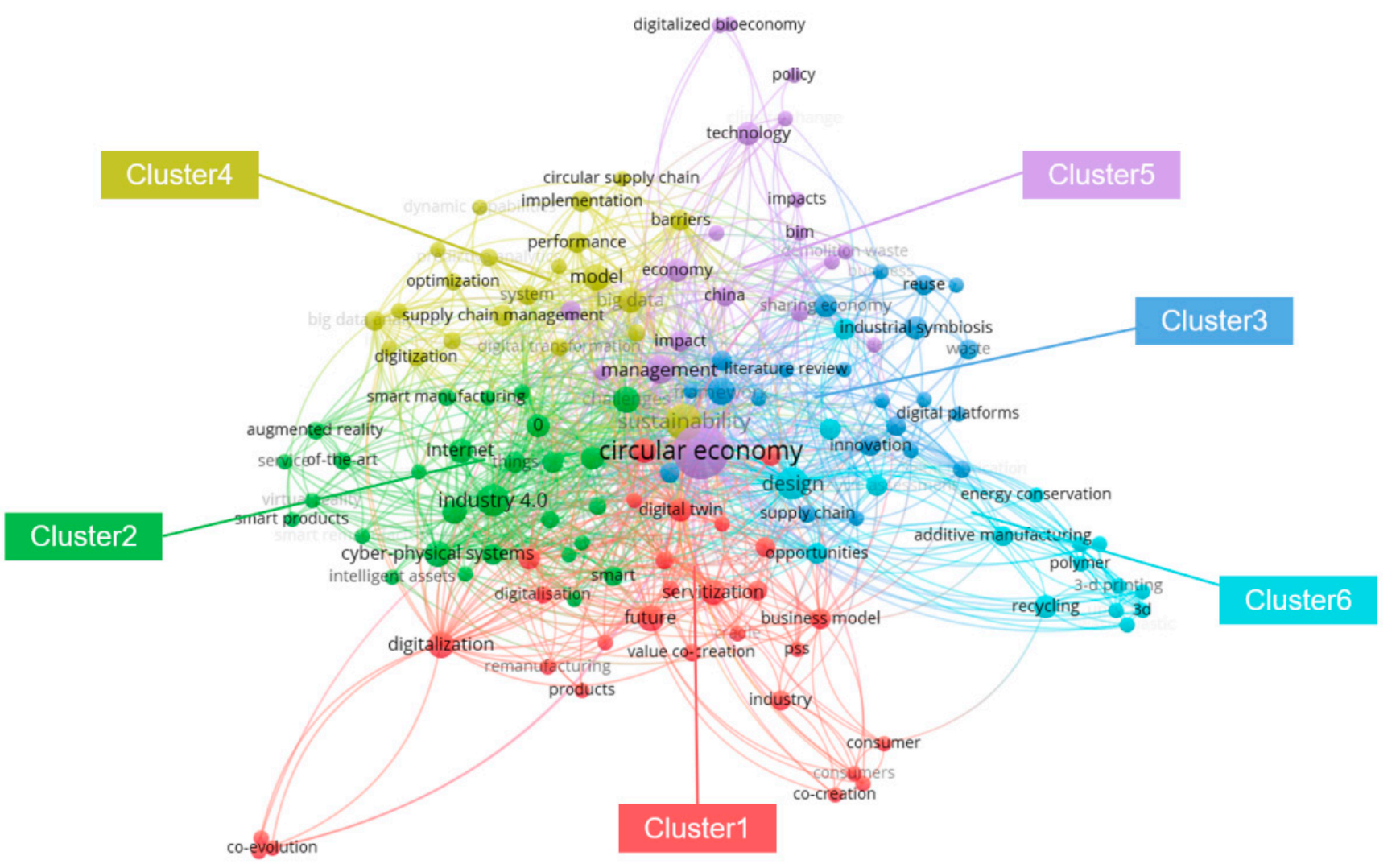

Figure 4. Keyword network visualization of CE \& DE from year 2016 to 2020 via VOSviewer.

The Cluster terms that are more closely related to the topic of CE \& DE are CE, sustainability, industry 4.0 (I4.0), design, management, and framework. Table 1 shows the high-frequency keywords derived from the VOSviewer keyword co-occurrence analysis, which specifies a minimum number of keyword appearances of ten times, including their color representation, cluster, occurrence frequency, and total link strength.

Table 1. High-frequency keywords of CE \& DE from year 2016 to 2020 via network visualization of VOSviewer.

\begin{tabular}{|c|c|c|c|c|}
\hline Color ${ }^{1}$ & Cluster & Keyword & Occurrence & Total Link Strength \\
\hline & 5 & $\begin{array}{c}\text { Circular } \\
\text { economy (CE) }\end{array}$ & 81 & 449 \\
\hline & 4 & Sustainability & 24 & 161 \\
\hline & 2 & $\begin{array}{c}\text { Industry } 4.0 \\
\text { (I4.0) }\end{array}$ & 17 & 131 \\
\hline & 6 & Design & 17 & 117 \\
\hline & 5 & Management & 12 & 91 \\
\hline & 3 & Framework & 11 & 83 \\
\hline
\end{tabular}

${ }^{1}$ The colors in the table are in line with colors from Figure 4.

\subsubsection{Overlay Visualization}

The research hotspots of period of year can be found in the overlay visualization, which can also help with predicting future research trends. Figure 5 indicates a visualization of the keywords in all the literature searches in this study from the year 2016 to 2020, presenting the past to the present colors that are from purple, blue gradient to green, and yellow. In terms of weight, total contact strength and the color of the key words are illustrated in Figure 5, and the research hot spots of each year are summarized in Table 2. 


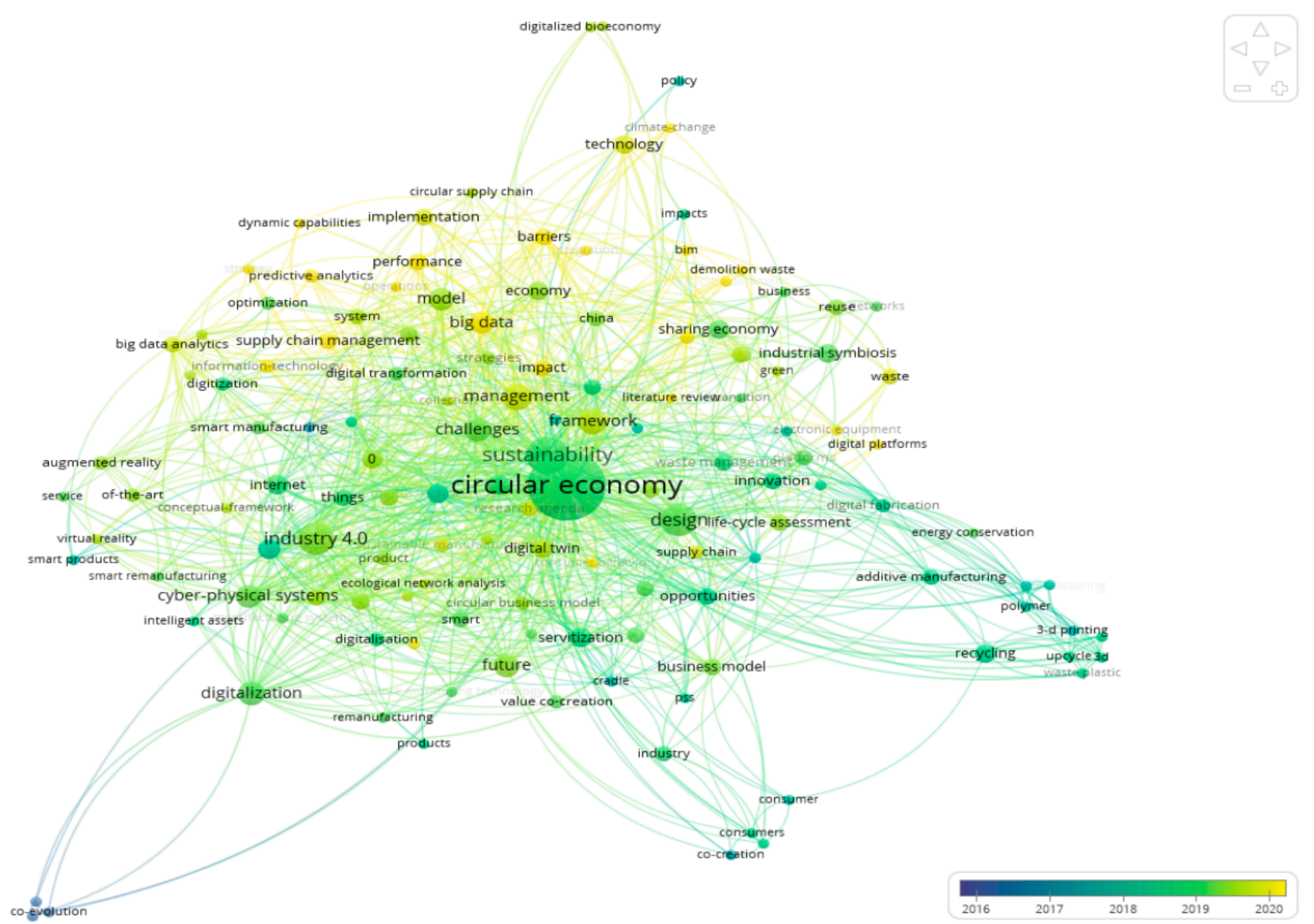

Figure 5. Keywords overlay visualization of CE \& DE from year 2016 to 2020 via VOSviewer.

Table 2. Hot research keywords of CE \& DE in recent five years (year 2016 to 2020) via overlay visualization of VOSviewer.

\begin{tabular}{|c|c|c|}
\hline Year & Color Range $^{1}$ & Keywords \\
\hline 2016 & & $\begin{array}{l}\text { co-evolution, transdisciplinary, responsible } \\
\text { business management, digital intelligence }\end{array}$ \\
\hline 2017 & & co-creation, 3-D printing, policy \\
\hline 2018 & & $\begin{array}{l}\text { internet of things (IoT), additive manufacturing } \\
\text { (AM), digital technologies, recycling }\end{array}$ \\
\hline 2019 & & $\begin{array}{c}\text { CE, sustainability, design, servitization, } \\
\text { digitalization, sharing economy, cyber-physical } \\
\text { systems, digital twin }\end{array}$ \\
\hline 2020 & & $\begin{array}{l}\text { big data, supply chain management, barriers, } \\
\text { impact, performance, strategy, demolition waste, } \\
\text { information-technology, consumer behavior, } \\
\text { building information modelling/management } \\
\text { (BIM), life cycle assessment, climate-change }\end{array}$ \\
\hline
\end{tabular}

${ }^{1}$ The color range in the table is in line with the color range from Figure 5.

The hot research keywords of CE \& DE in the recent five years, i.e., 2016 to 2020, are summarized in the following five schemes:

(1) Collabrative working method: co-evolution, transdisciplinary, co-creation, design;

(2) Economy: responsible business management, sharing economy, consumer behavior; 
(3) Emerging information and technology: digital intelligence, 3-D printing, IoT, AM, cyber-physical systems, digital twin, big data, building information modelling/ management (BIM);

(4) Initiative: policy, barriers, impact, performance, strategy;

(5) Waste associated sustainability: recycling, demolition waste, life cycle assessment, supply chain management.

In the latest research hotspots in 2020, big data and supply chain management appear more frequently, indicating that this research hotspot has more studies involved or may have a strong link with the prominent research topics, which are followed by barriers, impact, and performance. The least frequent topics are demolition waste, informationtechnology, consumer behavior, life cycle assessment, climate-change, and BIM, which could have great research potential in the future.

\subsection{Multidisciplinary Research on the Literature on $C E$ and $D E$}

The section associated with Step 4 of the research method flow in Figure 1 aims to explore the $\mathrm{CE}$ and $\mathrm{DE}$ research within a multidisciplinary context. The VOSviewer software is used to select the subject areas for generating effective keyword co-occurrence and analysis.

\subsubsection{Classification and Selection of the Subject Areas of CE and DE}

According to the classification of "research areas" in the WoS database, published articles are divided into 20 different subject areas, where the minimum number of records is 2, as shown in Figure 6. Among these subject areas, the most articles are in the field of ENGINEERING, followed by ENVIRONMENTAL SCIENCES ECOLOGY, and SCIENCE TECHNOLOGY OTHER TOPICS. The articles in each subject area were imported into VOSviewer for co-occurrence analysis. However, only seven subject areas, i.e., ENGINEERING, ENVIRONMENTAL SCIENCES ECOLOGY, SCIENCE TECHNOLOGY OTHER TOPICS, COMPUTER SCIENCE, BUSINESS ECONOMICS, MATERIALS SCIENCE, and OPERATIONS RESEARCH MANAGEMENT SCIENCE, can form effective keyword cooccurrence; as such, this study selects the seven subject areas for further investigation.

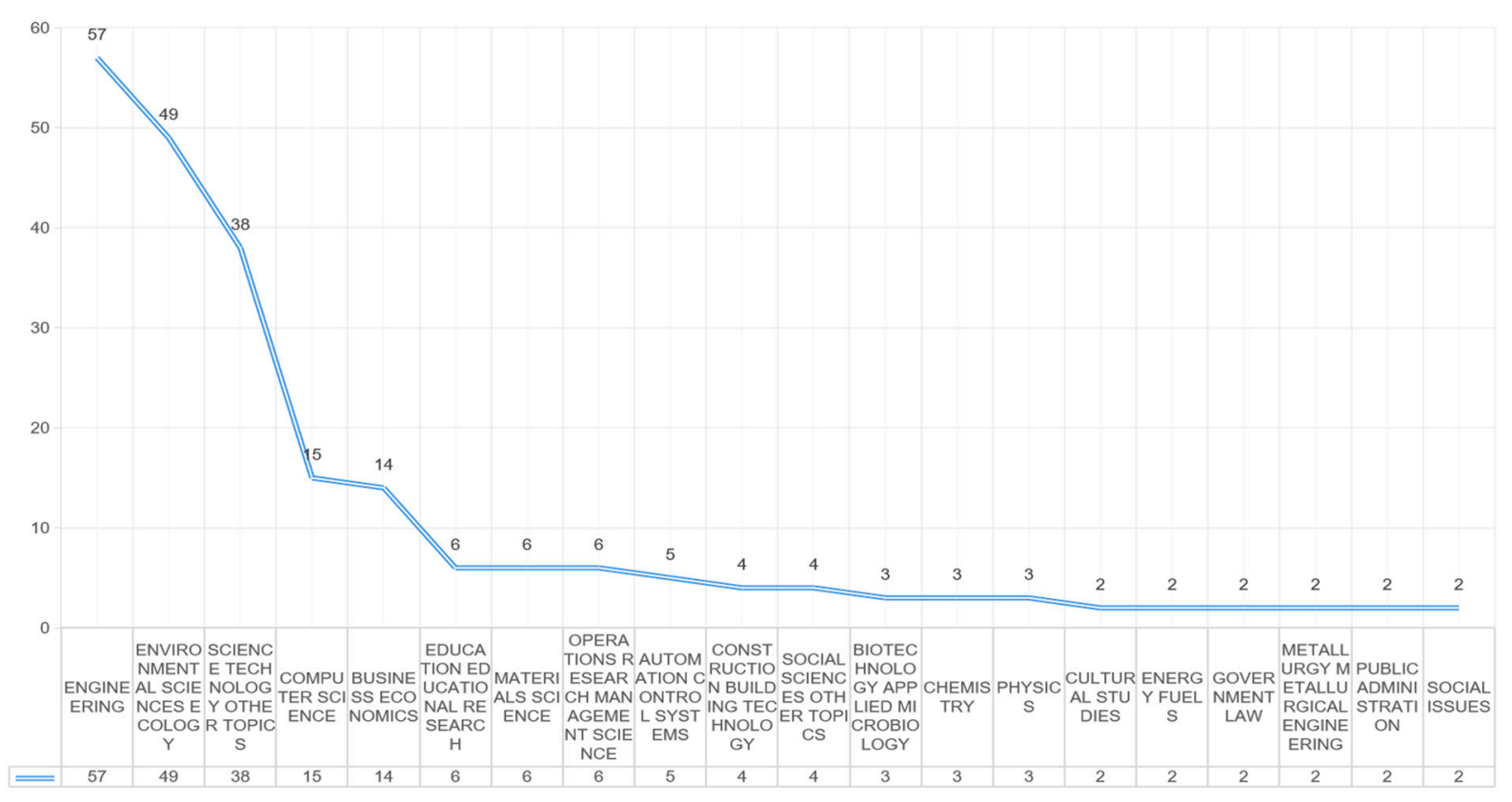

Figure 6. Number of published articles between 2016 and 2020 in various disciplines under the topic of CE \& DE.

Figure 7 shows the above-mentioned seven subject areas that can form effective keyword co-occurrences, and the article publication status, between 2016 and 2020. It can 
be seen that the field of ENGINEERING has the most publications and maintains the highest development trend. The number of publications ranked second is ENVIRONMENTAL SCIENCES ECOLOGY, with the first article was published in 2017, and the number of publications obtained in 2020 is the most in seven subject areas. MATERIALS SCIENCE and OPERATIONS RESEARCH MANAGEMENT SCIENCE began to develop gradually in 2018, with the fewest publications. The next step is to explore articles in the seven subject areas to reveal the status of multidisciplinary research and identify gaps and trends in the various disciplines.

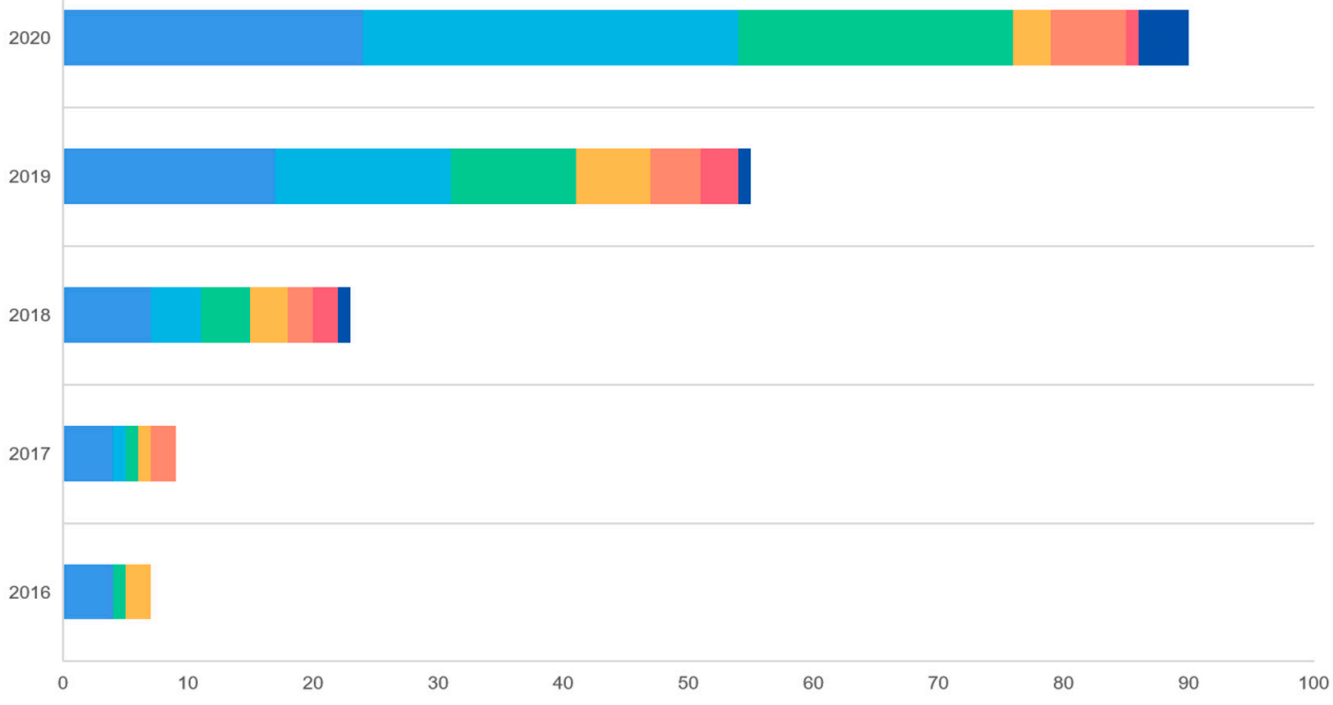

aNGINEERING -ENVIRONMENTAL SCIENCES ECOLOGY SCIENCE TECHNOLOGY OTHER TOPICS - COMPUTER SCIENCE

BUSINESS ECONOMICS

-MATERIALS SCIENCE

- OPERATIONS RESEARCH MANAGEMENT SCIENCE

\begin{tabular}{|c|c|c|c|c|}
\hline 2016 & 2017 & 2018 & 2019 & 2020 \\
\hline 4 & 4 & 7 & 17 & 30 \\
\hline 0 & 1 & 4 & 14 & 22 \\
\hline 2 & 1 & 4 & 6 & 3 \\
\hline 0 & 1 & 3 & 4 & 6 \\
\hline 0 & 2 & 2 & 3 & 1 \\
\hline
\end{tabular}

Figure 7. The number of published articles between 2016 and 2020 in different years in the seven subject areas in which effective keywords can be formed.

\subsubsection{Research Overview of the Seven Subject Areas of CE and DE}

\section{ENGINEERING;}

The articles in the ENGINEERING subject areas under the topic CE \& DE in WoS have been imported into VOSviewer to generate keyword co-occurrence terminology. As shown in Figure 8, the relationship with the topic CE \& DE is more closely related to CE, sustainability, design, I4.0, and cyber-physical systems, which are mainly distributed in three regions, i.e., yellow, purple, and red. The following three areas are summarized as CE and Design, I4.0 and Cyber-physical systems, and Sustainability. 


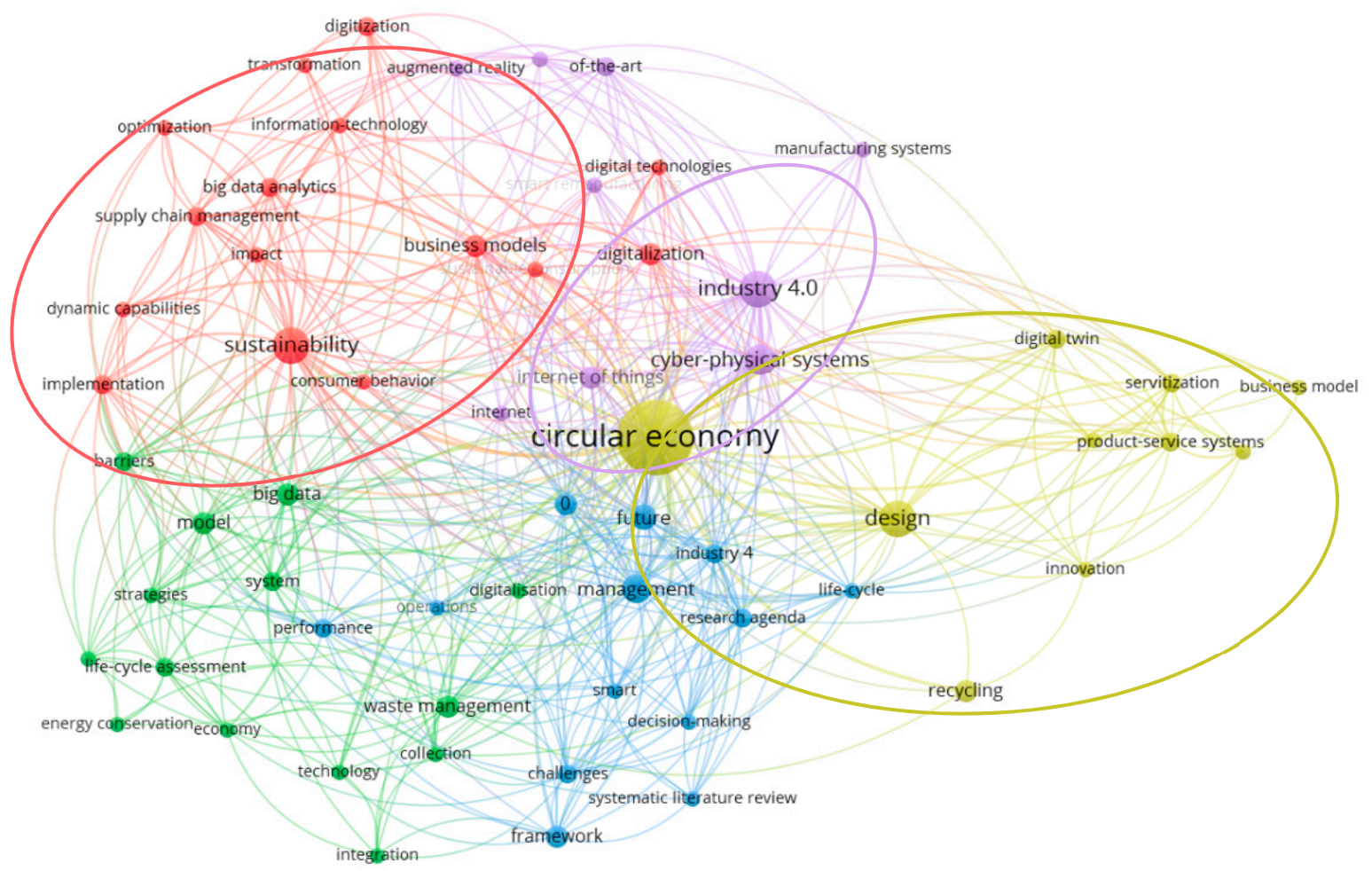

Figure 8. Keyword visualization of published articles between 2016 and 2020 in the field of ENGINEERING regarding CE \& DE.

As shown in Figure 8, the keywords that are closely related to "CE and Design" in the yellow area are digital twin, recycling, product-service systems (PSS), and servitization. Most articles on "CE and Design" mainly adopt mixed research methods [50-52], followed by case study methods [20,53,54]. In the field of ENGINEERING, the concept of CE is widely used, such as the areas or consumer market, procurement 4.0 (P4.0), and material recovery, of which most literature is about material recovery, mainly including Waste Electrical and Electronic Equipment (WEEE) and plastics. By and large, the literature argues that digital technology has the potential to promote a Circular Economy, while the life cycle of the product needs to be considered in the design. Digital technology is a key driver of circular economic development [29]. In the consumer market, it contributes to the success and promotion of short-term, mobile, access-based product-service systems (AB-PSS) [52]. It was also reported that digital procurement (P4.0) can improve business health by improving visibility and recovery, indirectly improving CE performance [55]. The use of digital technologies in waste management, such as robot technology, sensors, and digital image analysis, helps to improve the efficiency of waste disposal [56]. The use of distributed plastic recycling [54] and 3-D printing technology [57] in plastic recycling can improve material recovery rates. WEEE material recycling has been found to help improve WEEE recycling by deploying an IoT communication network to meet information needs and harnessing loT's potential domain in waste management [51]. However, poor product design and a lack of recovery infrastructure have hampered the recovery rate of key raw materials in WEEE [58]. Integrated design and production can improve waste production throughout the life cycle by avoiding isolated operations in the design and manufacturing sector [59]. Applying virtualization technology to design can be of great help in terms of updating modular and repairable products, which is a key factor in adopting a circular business model [60]. 
In the purple area, as shown in Figure 8, the key words to establish a closer relationship with "I4.0 and Cyber-physical systems" are IoT, smart re-manufacturing, business models, and digital technologies. Most articles on "I4.0 and Cyber-physical systems" focus on mixed research methods [56,61,62], followed by systematic literature [63-65]. In today's highly manual re-manufacturing process, a higher degree of automation is required to continue to expand the application of IoT, VR, and AR in remand to implement the I4.0 concept [63]. For the transformation of traditional manufacturing equipment into intelligent manufacturing to obtain high quality and low-cost output, the total manufacturing cost can be optimally reduced by optimizing product machine configuration; as well, the circular economy and cleaner production can be realized, in which products are distributed and produced on machines with low energy consumption and low machine cost [66]. I4.0 technologies, including additive manufacturing (AM), simulation, virtualization, and cloud computing, provide opportunities for sustainable manufacturing in environmental, social, and economic terms [65]. Kerin and Pham [62] show that changes in product ownership patterns will affect re-manufacturing, of which the development of PSS is seen as an opportunity for resource re-flow and value creation. Moreover, the key to success of I4.0 future re-manufacturing is to absorb existing and emerging digital technologies to shorten and strengthen the links between product manufacturers, users, and re-manufacturers [62]. In a highly driven and dependent $\mathrm{CE}$, the main challenges facing I4.0 are the lack of virtualization of automation systems, the lack of process design, and the lack of knowledge management systems; for example, the Malaysian palm oil industry can enhance the potential for new business development by promoting clean technology innovation [50].

As indicated in the red area from Figure 8, the key words to establish a closer relationship with "Sustainability" are mainly business models, supply chain management, big data analytics, and consumer behavior. Most of the articles on "Sustainability" focus on case studies $[23,67]$ and mixed research methods $[61,68]$. Business models play an important role in digital co-existing platforms, sustainable industries, and product life extensions. Digital sharing platforms identify with the $\mathrm{CE}$ while tending towards a limited number of principles, goals, and profit-oriented business models [68]. Moving towards CE involves changes in two main areas: management changes and legislative changes. In addition, the creation of the $\mathrm{CE}$ can be facilitated by introducing new technologies and digital innovations [69]. At present, the digitalization of enterprises is paying great attention to new technologies such as loT, blockchain, and more innovative business models. The new business model focuses on reduction, collection, reuse, recovery, and recycling [69]. Ertz et al. [70] analyzed business models on product lifetime extension and found that improving product nature through design is less prevalent than product nature strategies, such as maintenance (maintenance, recommendation, training, and consultation), recovery (re-manufacturing and repair), redistribution, and access schemes.

\section{ENVIRONMENTAL SCIENCES BIOLOGICAL;}

From the keyword visualization in the field of ENVIRONMENTAL SCIENCES BIOLOGICAL, as shown in Figure 9, the topic of CE \& DE is closely related to CE, sustainability, framework, and I4.0, and mainly distributed in three regions, i.e., yellow, red, and green. 


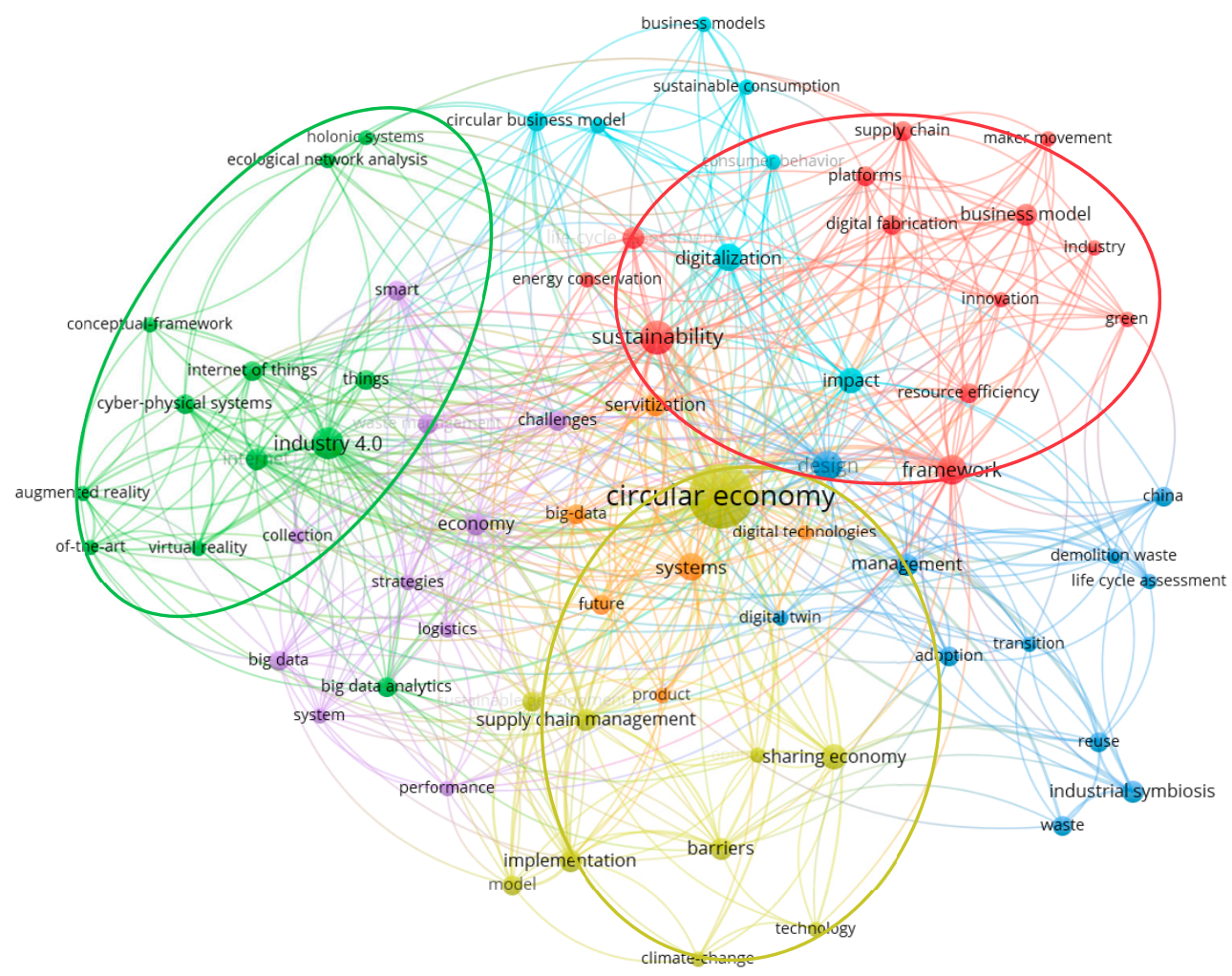

Figure 9. Keyword visualization of published articles between 2016 and 2020 in the field of ENVIRONMENTAL SCIENCES BIOLOGICAL regarding CE \& DE.

As shown in Figure 9, in the yellow area, the keyword to establish a closer relationship with " $\mathrm{CE}$ " is mainly associated with sharing economy. Most articles on the "CE" focus on case studies [71-73], followed by mixed research methods [51,56,74]. Under the widespread use of digital technology, digital sharing platform has been developed rapidly, which has also greatly promoted the development of sharing economy. Consumer preferences are a major influence on digital sharing platforms. Digital sharing platforms identify with the CE while tending towards a limited number of principles, goals, and profit-oriented business models [68], in which the main impact of digital platforms on sustainable development is information consumption and production [74]. The sharing economy benefits many sectors of society, where sustainable practices and service-based and disruptive technologies work with the sharing economy to improve sustainable value chains [75]. However, an analysis of the current state of sharing in Russia [74] found that the use of most types of sharing are still in their infancy, and that the popularity of the Internet and the quality of digital platform services needs to be improved. Convenience and mobility can influence consumption and use decisions, and dematerialization has greater potential than improved device aggregation and material efficiency, which requires a significant increase in consumer interest in technological products and understanding of product capabilities [76]. Consumer digital confidence is also likely to influence their attitudes towards digital services and products in other applications [52]. Consumers can reduce barriers to distrust by using the experience of shared models in the learning process [74].

As indicated in the red area from Figure 9, the keywords to establish a closer relationship with "Sustainability and framework" are mainly related to business model, life-cycle assessment, and digital fabrication. In order to foster the development of CE, computer simulation technology is used to promote green building in the construction industry, and BIM is introduced in the materialization stage of building and the end-of-life stage. The maker movement refers broadly to people engaged in the creative production of artifacts in their daily lives and in sharing the creation process and products in physical and digital forums [77], which also brings new environmental values in reducing environmental 
challenges. For energy-efficient green buildings, computer simulation provides a quick and effective tool for predicting energy consumption and carbon emissions throughout the life cycle of a building and allows one to systematically explore the design space for optimal solutions [78]. The use of prefabricated structures in the construction process can significantly promote $\mathrm{CE}$ through more precise quantitative production and less waste generation [79]. BIM helps with making life cycle assessments more project-specific and simplifying the complex processes of calculating materials and energy consumption [79]. Further, the maker movement can contribute to sustainability by promoting a CE through its culture of restoration, recycling, and upgrading [80,81]. However, there are some negative environmental impacts of the maker movement, for example, too many fine wires of 3-D printing are not recycled [81].

In the green area, as shown in Figure 9, the keywords to establish a closer relationship with "I4.0" are mainly focused on IoT, cyber-physical systems, and VR. Digital technology is an indispensable part of the development of I4.0. Enterprises are introducing digital technologies such as the IoT, VR, and intelligent robots to facilitate the transition to digital enterprises. These include auto parts remanufacturing, improved waste management, harsh environments, and WEEE removal. The current implementation of the IoT loop strategy primarily supports two phases of use, namely, use efficiency and product life cycle extension [82]. The IoT has been used to explore the remanufacturing process of automotive components aiming at extending products' life [83]. Applying robotics to waste management can reduce people's heavy physical classification and free them from a work area that affects health, e.g., noise, dust, pollutants, etc.; although there are selected limitations for the efficient application of robotics, such as specific materials and specific technical limitations [56]. VR technology enables companies to improve the ability to recycle valuable components during WEEE removal and improve material repair to improve their circularity [72]. Applying I4.0 technology throughout a product's life cycle, digitization has made a positive contribution to environmental sustainability by improving resource and information efficiency. However, there is also a negative environmental burden due to the increased consumption of resources and energy, as well as the waste and emissions resulting from the manufacture, use, and disposal of hardware [84].

\section{SCIENCE TECHNOLOGY OTHER TOPIC;}

As shown in Figure 10, there are two clusters of article keywords, i.e., "CE" and "Sustainability" in SCIENCE TECHNOLOGY OTHER TOPIC areas regarding CE \& DE.

Figure 10 indicates a closer link between the " $\mathrm{CE}$ " and design, systems, frameworks, and business models. Product life extension can promote the development of CE through enhancing product design, allowing tracking of product activities to prevent improper use, enhancing technical support, providing preventive and predictive maintenance, and enhancing product upgrades [23]. Franquesa and Navarro [85] propose a recycling product license by which the relevant organization protects the reuse of the device until there is no longer a need or possibility of reuse of the device that will be recycled to ensure the maximum service life of the device.

As shown in Figure 10, "Sustainability" and I4.0 are closely associated with each other. Digitalization accelerates sustainability transformation, through which I4.0 has sustainability functions. Achieving sustainability via ICTs plays a crucial role in accelerating economic processes [86]. In the context of I4.0 enhanced by advanced technologies, such as IoT, cloud computing, information physical systems, digital twinning, and big data analysis, numerous opportunities are provided for the implementation of cleaner production strategies and the development of intelligent manufacturing [87]. Ghobakhloo's analysis shows that economic issues of sustainability, such as productivity and business model innovation, are direct results of I4.0, paving the way for the development of more remote environmental and social functions towards sustainability, such as energy sustainability, harmful emission reduction, and social welfare improvements [61]. 


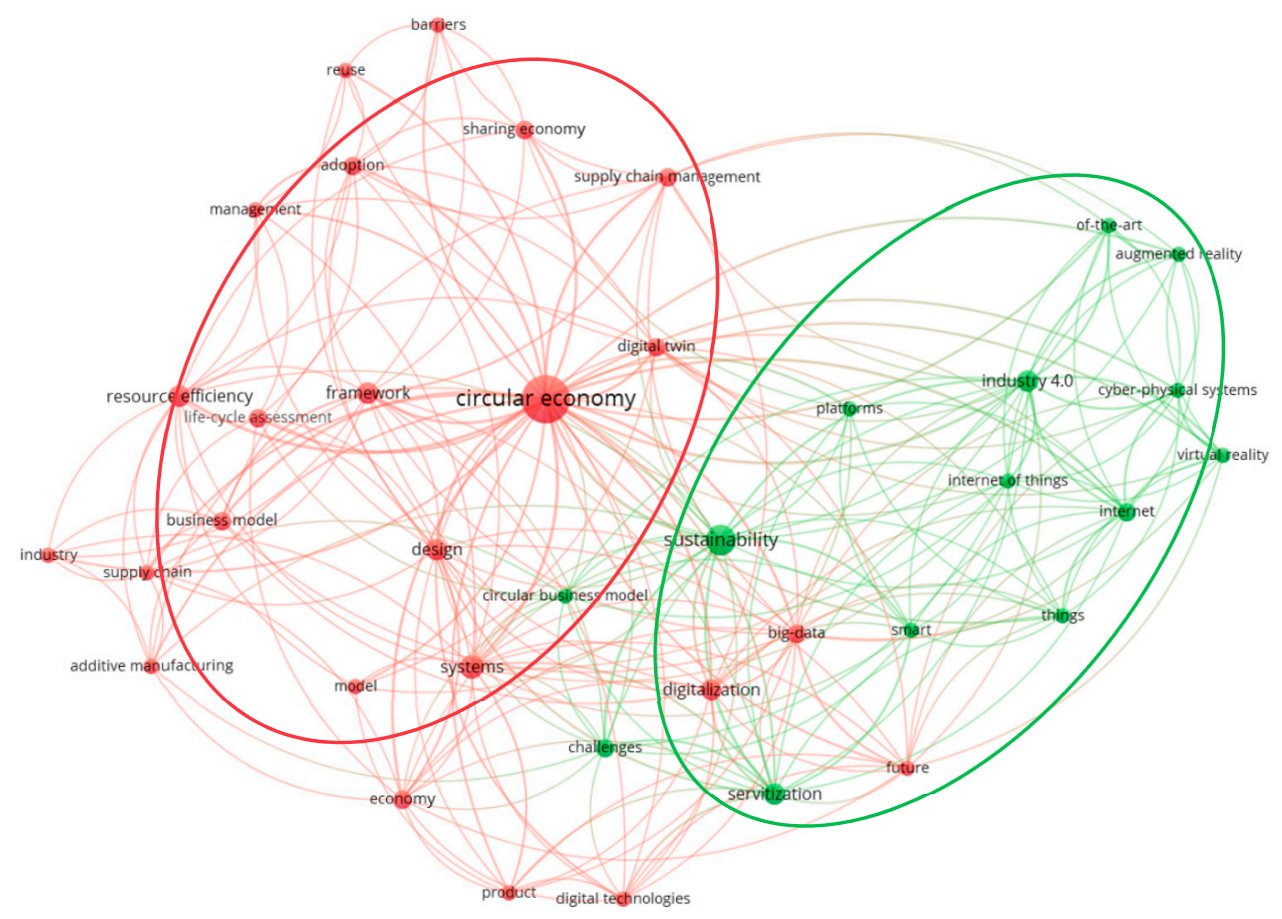

Figure 10. Keyword visualization of published articles between 2016 and 2020 in the field of SCIENCE TECHNOLOGY OTHER TOPIC regarding CE \& DE.

\section{COMPUTER SCIENCE;}

Figure 11 exhibits 10 co-occurrence keywords in the field of COMPUTER SCIENCE, of which the central keyword is CE. Over the past few years, advances in information technology (IT) have enabled organizations in many departments to digitally transform [88]. The rapid development of ICTs has led to a widespread digital transformation (i.e., digitalization), in which physical products can be easily digitized and seamlessly connected in virtual spaces [89]. The development and integration of information technology allows the entire business model to be reshaped to support the creation of new forms of value for the organization [90]. The rapid development of the ICTs industry and the development of global connectivity in promoting economic and social change in many parts of the world plays an important role; however, on the topic of ICTs, developing countries and developed countries, rural and urban, and men and women, there still exists inequality in terms of using the Internet [91].

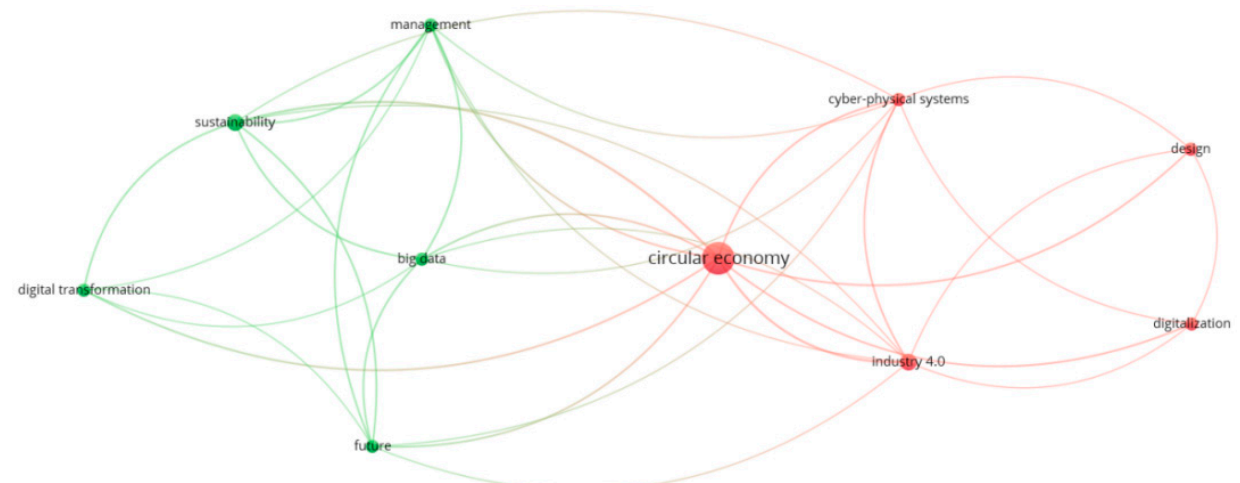

Figure 11. Keyword visualization of published articles between 2016 and 2020 in the field of COMPUTER SCIENCE regarding CE \& DE.

\section{BUSINESS ECONOMICS;}


In the field of BUSINESS ECONOMICS in CE \& DE, there are a total of eight keyword co-occurrences, as shown in Figure 12. The keywords with higher weighting are " $\mathrm{CE}$ " and "sustainability".

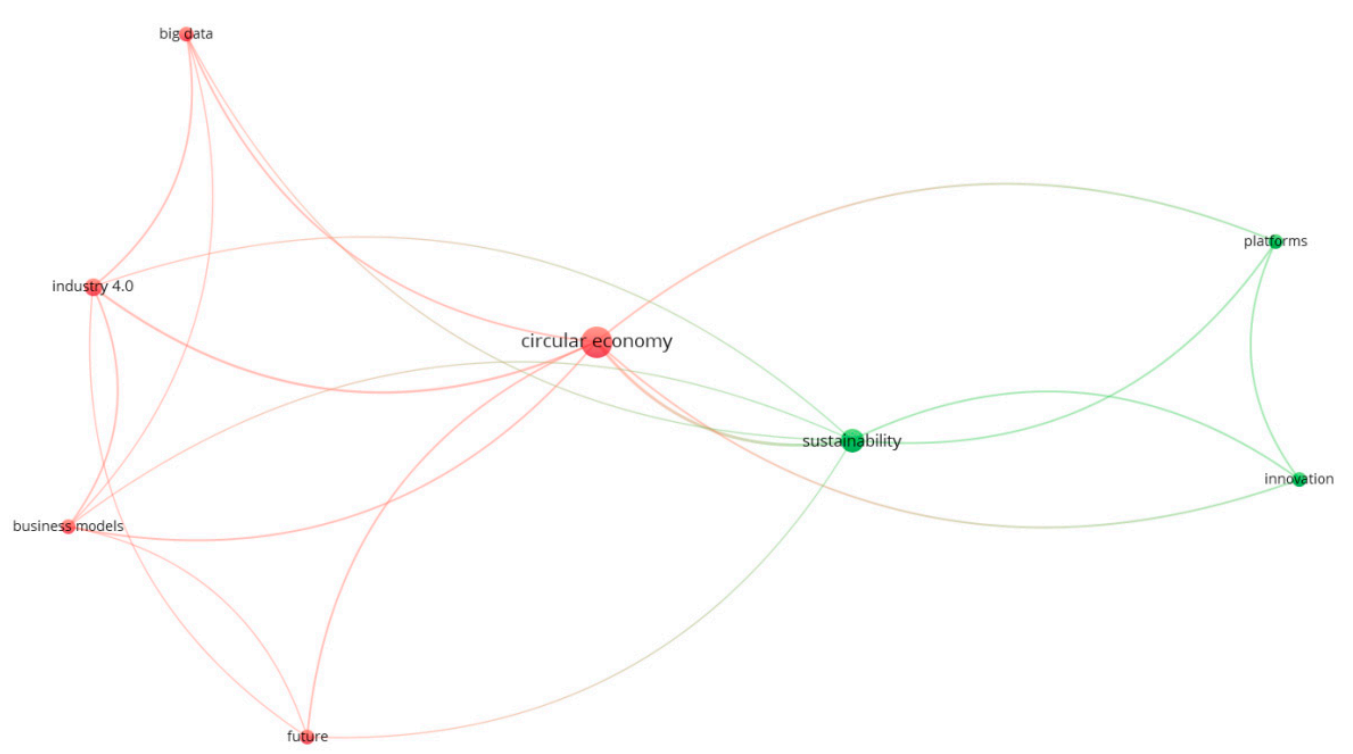

Figure 12. Keyword visualization of published articles between 2016 and 2020 in the field of BUSINESS ECONOMICS regarding CE \& DE.

Circular product design is a relatively new design strategy to implement circular products, where AM has great potential in circular product design, and it seems that AM is particularly suitable for customizing parts to suit existing products and create new opportunities for material recycling [92]. That said, AM technologies are still an immature technology in terms of digital representations, materials, and their integration with existing technology systems and emerging technologies [93]. In addition, the textile industry has also introduced circular apparel. Consumers appreciate the idea of recycling textile waste to produce new clothes, through which additional value for consumers can be created by seizing communication opportunities, communicating through multiple channels, enhancing the shopping experience, and adding digital services [94]. However, the recycling of apparel faces a number of obstacles. The main obstacles of textile-to-textile recycling systems are: limited technology that challenges the separation of materials; the high cost of researching, developing, and establishing supporting logistics; the complexity of the supply chain, including many stakeholders involved in product development [95]. Studies have shown that closing industrial cycles by better utilizing raw materials, converting waste into energy, and refurbishing components of products contributes to environmental sustainability and provides new business opportunities for industrial actors [96]. Digital transformation reinforces the impact of structural change on wage inequality. Especially in the medium term, wage inequality has risen more than the baseline predicts [97].

\section{MATERIALS SCIENCE;}

As shown in Figure 13, in the field of MATERIALS SCIENCE in CE \& DE, when the minimum number of appearances is limited to two, there are seven co-occurrence keywords associated with polymer recycling in 3-D printing. 


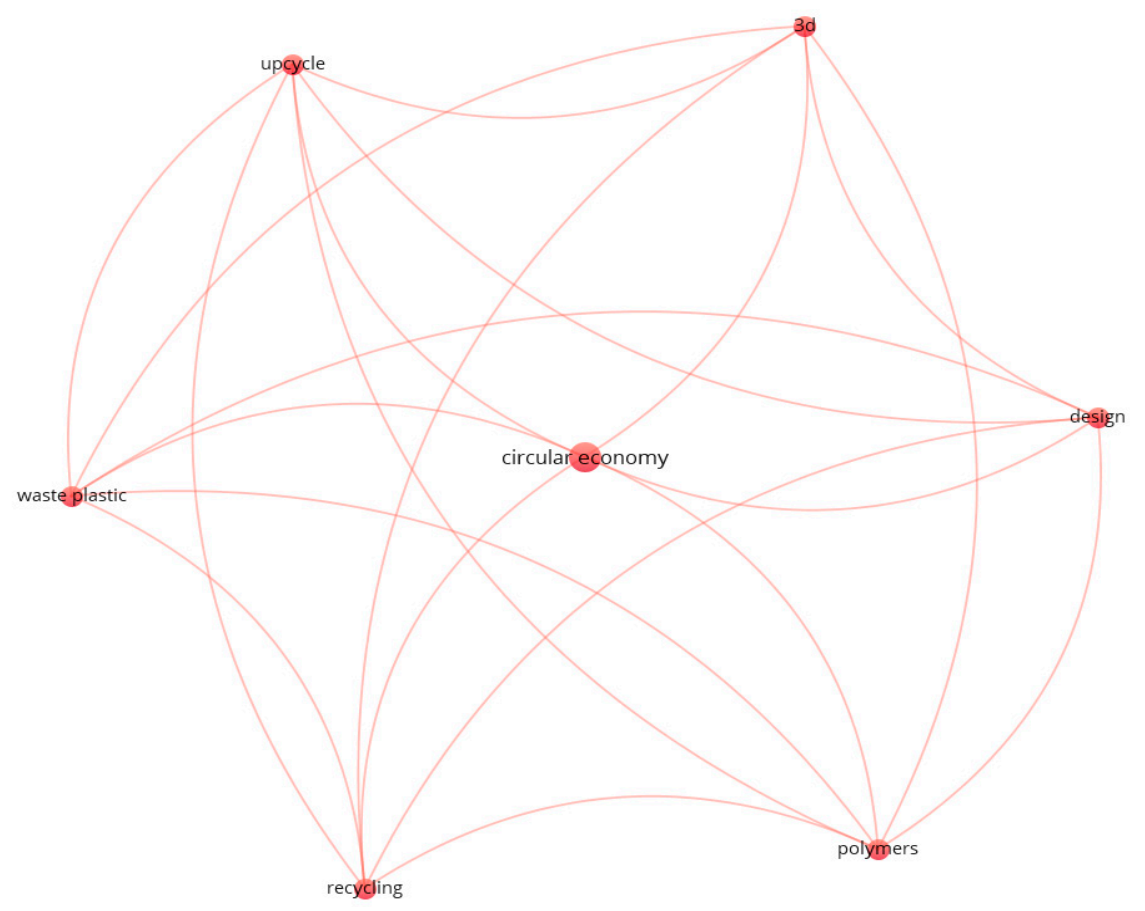

Figure 13. Keyword visualization of published articles between 2016 and 2020 in the field of MATERIALS SCIENCE regarding CE \& DE.

Recycling materials from waste plastics can not only contribute to environmental protection, but also bring considerable economic benefits. The fused particle fabrication/ fused granular fabrication 3-D printing technology enables energy-efficient production of a wide range of large-scale, high-value sporting products [98]. For some products, the high-capacity use of the open source Gigabot $X$, which is a large-scale recycled plastic 3-D printer, has considerable profit potential and return on investment (e.g., more than $1000 \%$ ), while the Gigabot $X$ prints materials 6.5 to 13 times faster than conventional printers without any reduction in mechanical performance [98]. Byard et al. [57] show that using locally sourced shredded plastics is not only the best environmental option, but also the most economical.

\section{OPERATIONS RESEARCH MANAGEMENT SCIENCE;}

From Figure 14, there are 10 co-occurrence keywords in the field of OPERATIONS RESEARCH MANAGEMENT SCIENCE associated with CE \& DE, of which the minimum number of appearances is limited to two. The central keyword is "CE", which includes digital procurement, food logistics, and distribution under new trends. P4.0 is the digitization of procurement activities to increase efficiency and achieve process automation [99]. Melkonyan et al. [100] highlight the important role of the logistics sector in proactive innovation in services, making it easier for customers to make sustainable choices. For the level of delivery, AM can improve outbound logistics by shortening the supply chain and delivery time and distance [101]. 


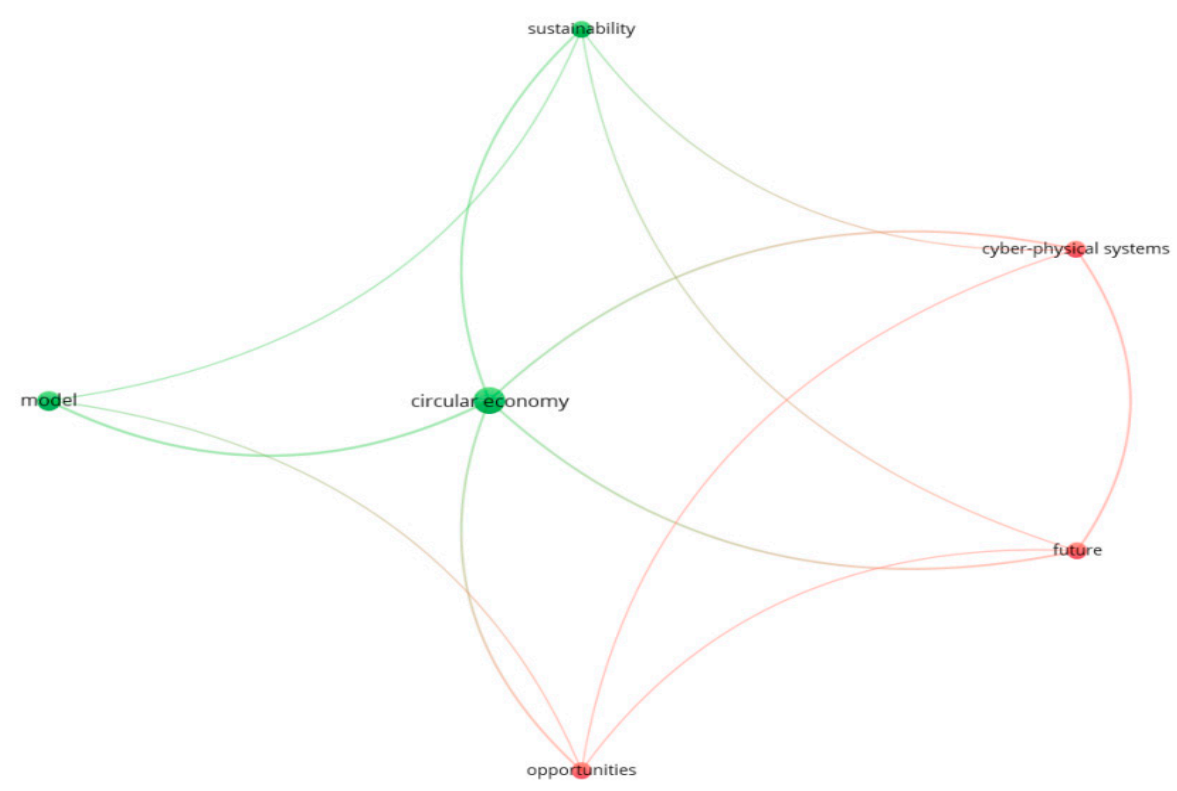

Figure 14. Keyword visualization of published articles between 2016 and 2020 in the field of OPERATIONS RESEARCH MANAGEMENT SCIENCE regarding CE \& DE.

\subsection{Life Cycle Stages and Application Areas in CE and DE}

In accordance with Step 5 of the research methodology process in Figure 1, the results of $\mathrm{CE}$ and DE publications across whole life cycle stages and their respective application areas are presented and discussed in this section.

Sixty articles related to life cycle stages and application areas were identified from the literature under the topic of CE \& DE. The life cycle stages are threefold [23,61]: (i) the Start stage (design, procurement, and manufacturing and production activities); (ii) the Intermediate stage (transportation and packaging, consumption and use, and repair and maintenance); (iii) the End stage (deconstruction/disassembly, reuse/remanufacturing/recycling, and waste disposal).

At the Start of Life Cycle Stage, there is more research in the manufacturing and production phase, followed by the design and the procurement phases, as shown in Table 3. The application areas in the manufacturing and production phase include manufacturing $[39,79]$, redistribution manufacturing [53,102], smart manufacturing $[103,104]$, smart mobile products [105], AM [106], and palm oil production industry [50]. The design phase applications encompass smart product development [107], high-rise building design [108], autonomous mobile robots [109], digital bio-economy [110], and urban innovation [111]. Finally, the procurement phase is mainly focused on the application of P4.0 [55,99].

Table 3. The Start of Life Cycle Stage and application areas of the literature of CE \& DE from year 2016 to 2020.

\begin{tabular}{|c|c|c|c|c|c|}
\hline \multirow{2}{*}{$\begin{array}{l}\text { Literature } \\
\text { Source }\end{array}$} & \multirow[b]{2}{*}{ Year } & \multicolumn{3}{|c|}{ The Start of Life Cycle Stage } & \multirow[b]{2}{*}{ Application Areas } \\
\hline & & Design & Procurement & $\begin{array}{l}\text { Manufacturing } \\
\text { and Production }\end{array}$ & \\
\hline $\begin{array}{l}\text { Abdul-Hamid } \\
\text { et al. }\end{array}$ & 2020 & & & + & $\begin{array}{l}\text { I4.0 is applied to palm oil production } \\
\text { industry, planting industry }\end{array}$ \\
\hline Bag et al. & 2020 & & + & & Digital Procurement $4.0(\mathrm{P} 4.0)$ \\
\hline Hao et al. & 2020 & & + & + & $\begin{array}{l}\text { BIM, materialization stage of buildings, } \\
\text { prefabriced structures }\end{array}$ \\
\hline $\begin{array}{l}\text { Gonzalez- } \\
\text { Varona } \\
\text { et al. }\end{array}$ & 2020 & & & + & $\begin{array}{c}\text { Spare parts AM, business model, small and } \\
\text { medium-sized enterprises }\end{array}$ \\
\hline
\end{tabular}


Table 3. Cont.

\begin{tabular}{|c|c|c|c|c|c|}
\hline \multirow[b]{2}{*}{$\begin{array}{l}\text { Literature } \\
\text { Source }\end{array}$} & \multirow[b]{2}{*}{ Year } & \multicolumn{3}{|c|}{ The Start of Life Cycle Stage } & \multirow[b]{2}{*}{ Application Areas } \\
\hline & & Design & Procurement & $\begin{array}{l}\text { Manufacturing } \\
\text { and Production }\end{array}$ & \\
\hline Fisher et al. & 2020 & & & + & $\begin{array}{l}\text { Waste management, wastewater pricing, } \\
\text { process manufacturing systems }\end{array}$ \\
\hline Bag et al. & 2020 & & + & & $\begin{array}{l}\text { Purchaser business process, information } \\
\text { processing capability, P4.0 }\end{array}$ \\
\hline Nogueira et al. & 2019 & + & & & City innovation \\
\hline Bausys et al. & 2019 & + & & & $\begin{array}{c}\text { Autonomous mobile robot, exploration of } \\
\text { the harsh environment }\end{array}$ \\
\hline Watanabe et al. & 2019 & + & & & Digital bioeconomy \\
\hline Bertin et al. & 2019 & + & & & $\begin{array}{c}\text { High-rise building design, structural } \\
\text { detachability, material reuse }\end{array}$ \\
\hline Miehe et al. & 2019 & & & + & $\begin{array}{c}\text { Biotechnology Interface (BTI) Engineering, } \\
\text { biological and technical manufacturing } \\
\text { systems }\end{array}$ \\
\hline Schischke et al. & 2019 & + & & + & $\begin{array}{l}\text { Smart mobile products modular, printed } \\
\text { circuit boards, cycle design }\end{array}$ \\
\hline $\begin{array}{l}\text { Tomiyama } \\
\text { et al. }\end{array}$ & 2019 & + & & & Smart product development \\
\hline Kusiak & 2019 & & & + & Smart manufacturing \\
\hline Moreno et al. & 2017 & & & + & Re-distributed manufacturing \\
\hline $\begin{array}{l}\text { Prendeville } \\
\text { et al. }\end{array}$ & 2016 & & & + & Redistribution of manufacturing \\
\hline
\end{tabular}

+ indicates that the literature contains the content.

Table 4 indicates that studies at the Intermediate of Life Cycle Stage focuses on 'Consumption' and 'Use' phase, followed by the 'Transportation' and 'Packaging' phase and 'Repair' and 'Maintenance' phase. The main application areas are the consumption and use of digital sharing platforms $[23,52,68,74,76]$, the transportation and packaging of food [100] and building prefabricated materials [79], and the repair and maintenance of the telecommunications industry [112].

Table 4. The Intermediate Life Cycle Stage and application areas of the literature of CE \& DE from year 2016 to 2020.

\begin{tabular}{|c|c|c|c|c|c|}
\hline \multirow[b]{2}{*}{$\begin{array}{l}\text { Literature } \\
\text { Source }\end{array}$} & \multirow[b]{2}{*}{ Year } & \multicolumn{3}{|c|}{ The Intermediate Life Cycle Stage } & \multirow[b]{2}{*}{ Application Areas } \\
\hline & & $\begin{array}{l}\text { Transportation } \\
\text { and Packaging }\end{array}$ & $\begin{array}{c}\text { Consumption and } \\
\text { Use }\end{array}$ & $\begin{array}{l}\text { Repair and } \\
\text { Maintenance }\end{array}$ & \\
\hline Tunn et al. & 2020 & & + & & $\begin{array}{l}\text { Consumer markets, mobile } \\
\text { access-based product-service } \\
\text { systems, digital services, consumer } \\
\text { attitudes and experiences }\end{array}$ \\
\hline $\begin{array}{l}\text { Melkonyan } \\
\text { et al. }\end{array}$ & 2020 & + & & & Food industry \\
\hline $\begin{array}{l}\text { Schwanholz } \\
\text { and Leipold }\end{array}$ & 2020 & & + & & Digital sharing platform \\
\hline Kasulaitis et al. & 2020 & & + & & $\begin{array}{l}\text { Electronics, materials, consumer } \\
\text { preferences }\end{array}$ \\
\hline Hao et al. & 2020 & + & & & $\begin{array}{l}\text { BIM, materialization stage of } \\
\text { buildings, prefabriced structures }\end{array}$ \\
\hline Revinova et al. & 2020 & & + & & Share economy, share platform \\
\hline $\begin{array}{l}\text { El Hilali and El } \\
\text { Manouar }\end{array}$ & 2019 & & + & + & $\begin{array}{l}\text { Telecommunications industry, } \\
\text { digital transformation }\end{array}$ \\
\hline $\begin{array}{l}\text { Bressanelli } \\
\text { et al. }\end{array}$ & 2018 & & + & & $\begin{array}{l}\text { Digital technology capabilities, } \\
\text { business models }\end{array}$ \\
\hline
\end{tabular}

+ indicates that the literature contains the content. 
Overall, most studies are at the End of Life Cycle Stage, as shown in Table 5, including Deconstruction/Disassembly, Reuse/Remanufacturing/Recycling, and Waste Disposal phases. Typical application areas include WEEE disassembly/recycling [51,58,72], reuse/remanufacture of consumer goods [113], automotive charging and energy storage systems [114], parts [83,115] and digital recorder [116], disposal of production and domestic wastes [117], disassembly/recycling and disposal of mixed energy and factory gases [118], metal parts [119], e-waste [120], and disassembly/recycling and reuse/remanufacturing of waste polymers [54,57,98], industrial wastes [121], and textile materials [94].

Table 5. The End of Life Cycle Stage and application areas of the literature of CE \& DE from year 2016 to 2020.

\begin{tabular}{|c|c|c|c|c|c|}
\hline \multirow[b]{2}{*}{ Literature Source } & \multirow[b]{2}{*}{ Year } & \multicolumn{3}{|c|}{ The End of Life Cycle Stage } & \multirow[b]{2}{*}{ Application Areas } \\
\hline & & $\begin{array}{l}\text { Deconstruction/ } \\
\text { Disassembly }\end{array}$ & $\begin{array}{c}\text { Reuse/ } \\
\text { Remanufacturing/ } \\
\text { Recycling }\end{array}$ & $\begin{array}{l}\text { Waste } \\
\text { Disposal }\end{array}$ & \\
\hline Charles et al. & 2020 & + & & & $\begin{array}{c}\text { Waste Electrical and Electronic } \\
\text { Equipment (WEEE) raw material } \\
\text { recycling }\end{array}$ \\
\hline Tuzun & 2020 & + & & + & $\begin{array}{c}\text { Hybrid energy recovery, plant gas } \\
\text { emissions, artificial intelligence } \\
\text { identification }\end{array}$ \\
\hline Rocca et al. & 2020 & + & & & $\begin{array}{l}\text { Virtual reality (VR), digital twins, } \\
\text { WEEE dismantling process }\end{array}$ \\
\hline Llamas et al. & 2020 & + & & + & $\begin{array}{c}\text { Metal production residues, fire } \\
\text { analysis }\end{array}$ \\
\hline $\begin{array}{l}\text { Garrido-Hidalgo } \\
\text { et al. }\end{array}$ & 2020 & + & & & $\begin{array}{l}\text { WEEE recycling, electric vehicle } \\
\text { batteries }\end{array}$ \\
\hline Charnley et al. & 2019 & & + & & $\begin{array}{c}\text { Automotive parts, simulation } \\
\text { technology }\end{array}$ \\
\hline Byard et al. & 2019 & + & + & & $\begin{array}{l}\text { Waste polymer recycling, 3-D } \\
\text { printing of recycled materials }\end{array}$ \\
\hline Dounavis et al. & 2019 & + & + & & $\begin{array}{l}\text { Digital online platforms, industrial } \\
\text { symbics, recycling of industrial } \\
\text { waste and as raw materials }\end{array}$ \\
\hline Makarova et al. & 2019 & & & + & $\begin{array}{c}\text { Disposal of production and } \\
\text { domestic wastes }\end{array}$ \\
\hline Vonk & 2018 & + & & + & $\begin{array}{l}\text { E-waste, attention economy, media } \\
\text { ecology }\end{array}$ \\
\hline $\begin{array}{l}\text { Woern et al. } \\
\text { Sitek et al. }\end{array}$ & 2018 & + & & & Recycled polymers in 3-D printing \\
\hline Vehmas et al. & 2018 & + & + & & $\begin{array}{l}\text { BGA part ball remanufacturing } \\
\text { Recycling textile waste, consumer } \\
\text { remanufacturing attitude }\end{array}$ \\
\hline Zhong and Pearce & 2018 & + & + & & $\begin{array}{l}\text { Computer waste, distributed } \\
\text { recycling remanufacturing, 3-D } \\
\text { printing }\end{array}$ \\
\hline Okorie et al. & 2018 & & + & & $\begin{array}{l}\text { Hybrid electric vehicles, electric } \\
\text { vehicles, charged energy storage } \\
\text { systems, remanufacturing }\end{array}$ \\
\hline Eden & 2017 & & + & & Free loop, consumer goods reuse \\
\hline Pamminger et al. & 2016 & & + & & $\begin{array}{c}\text { Digital recorder, redesign and } \\
\text { remanufacture }\end{array}$ \\
\hline
\end{tabular}

+ indicates that the literature contains the content.

In addition, applications throughout the Whole Life Cycle Stage are mainly associated with products, including smart PSS [89,122], recycling product management [85], and product life extension [70], followed by the construction industry, mainly in terms of computer simulation of the full life cycle stage [78] and life cycle information conversion and exchange [123], and the garment industry from textiles to textile recycling [95]. 
Further, for publications on CE \& DE with unclear or no relationship to life cycle stages, associations with their application fields include business models [20,124], supply chain management [67], closed-loop systems [96], industrial policies [125], information technology [126], digital transformation [97,127], smart assets [128], city social inclusion [129] and rural well-being [130], and environmental value [81].

\section{Discussion}

Multidisciplinary research is a key feature of the topic of CE \& DE, and its main subject areas include ENGINEERING and ENVIRONMENTAL SCIENCES ECOLOGY. Multidisciplinary promotion of $\mathrm{CE}$ is necessary to achieve sustainable implementation strategies, business modelling, and policy formulation [38,131,132]. Gan et al. [78] suggest that multidisciplinary design should be used in buildings to produce social technology solutions that include both environmental sustainability and human well-being. Some scholars suggest a multidisciplinary and integrated approach to research and understanding big data [133]. Lopez-Benitez et al. [134] highlight two key contributions to multidisciplinary driving IoT research to engender innovative solutions. However, the current research on $C E$ is hindered by different methods in the spread of CE, and little attention is paid to the multidisciplinary nature of circular realization [131]. In the study of CE \& DE, there are more published studies in ENGINEERING and ENVIRONMENTAL SCIENCES ECOLOGY areas. However, the areas of BIOTECHNOLOGY APPLIED MICROBIOLOGY, CHEMISTRY, PHYSICS, CULTURAL STUDIES, ENERGY FUELS, GOVERNMENT LAW, METALLURGY METALLURGICAL ENGINEERING, PUBLIC ADMINISTRATION, and SOCIAL ISSUES have less research.

Implementing policies across products' life cycle stages can improve resource utilization and reduce environmental pollution. The research content in the available literature associated with life cycle stages is largely dominated by considerations of end of life, including disassembly/recycling, reuse/recycling, and waste disposal. Studies have focused on distributed plastic recycling [54], WEEE raw material recycling [58], the reuse and remanufacturing of electric vehicle batteries [51], remanufacturing of auto parts [83], and waste disposal of mixed waste separation [56]. However, little research has concentrated on the design, procurement, transportation and packaging, and repair and maintenance life cycle phases. Charles et al. [58] raise the importance of the design phase, saying poor product design is a major obstacle to increased recycling rates. However, improving product nature through design is less prevalent than product nature strategies [70]. Sustainable growth and development require the introduction of innovative procurement concepts, in which the digitization of procurement activities can increase efficiency and realize automated processes while indirectly improving CE performance $[55,99]$. Traditional logistics supply chains have been disrupted by increased sustainability requirements, the application of new digital technologies, and changing consumer behavior. Melkonyan et al. [100] suggest that food logistics and distribution are facing new challenges. Tunn et al. [52] argue that sustainability can be improved by repairing and maintaining equipment, thereby potentially extending product life.

$\mathrm{DE}$ is a new economic form which has become a potential contributor to world economic growth, in which digital technology innovation is the core driving force [36]. The accelerated integration of digital technology with other fields can lead to breakthroughs in many fields and dimensions. For example, the key to the success of I4.0 future remanufacturing is to hug existing and emerging digital technologies [62], through which computer simulations provided a fast and effective tool for predicting energy consumption and carbon emissions throughout the life cycle of a building [78], and robotics can be implemented to mixed waste sorting and work environments that affect human health [56]. At the same time, researchers have made noticeable contributions to promoting circular supply chains, business model innovation, and the development of small and medium-sized enterprises. Furthermore, the integration of small and medium-sized enterprises into the digital platform ecology can reduce the cost of digital transformation of industrial enterprises [36]. 
However, Akimov [135] points out that the digital economic development programme has a strict structural deficiency in the direction of development, and that the criteria for evaluating the digital economic development system are considered a controversial issue. For example, the introduction of digital economic technology in Russia's fisheries is also facing serious challenges [136]. Equally, there is a strong demand for the use of digital technology in China to improve production and operation efficiency in government departments, schools, hospitals, institutions, and social and other organizations [137]. Therefore, in the future, with the development of a 5G network, artificial intelligence, IoT and other new network technologies, all countries in the world need to seize the opportunity to vigorously develop digital technology, such as digital governance, digital education, digital health care, and digital industry.

\section{Conclusions}

The aim of this paper is to explore the current research progress and trends of the integration of $\mathrm{CE}$ and DE. This is achieved through obtaining related publications via the core collection of the WoS database, which are imported into VOSviewer for keyword visualization analysis to explore the relationship between CE and DE. The main contributions and novelties of this paper are threefold: (1) this is the first attempt in this field to use the method of VOSviewer bibliometrics to conduct keyword co-occurrence research from a macro perspective to explore co-occurrence clusters, research hotspots, and development trends of the two keywords: "circular economy" and "digital economy"; (2) the paper scope and analysis were explored within multidisciplinary fields and journals, including ENGINEERING, ENVIRONMENTAL SCIENCES ECOLOGY, SCIENCE TECHNOLOGY OTHER TOPICS, COMPUTER SCIENCE, BUSINESS ECONOMICS, MATERIALS SCIENCE, and OPERATIONS RESEARCH MANAGEMENT SCIENCE, supported by the use of VOSviewer to intensely analyze the research status and application of various disciplines; (3) this paper adopts a life cycle stage approach to the findings by discussing related application fields, identifying the research gaps and trends, and providing recommendations to designers, decision makers, and researchers. Since published articles regarding CE \& DE have been increasing rapidly in last five years, 2016 to 2020, and the majority sources, totaling 15, are SUSTAINABILITY, JOURNAL OF CLEANER PRODUCTION, RESOURCES CONSERVATION AND RECYCLING, PROCEDIA CIRP, and SCIENCE OF THE TOTAL ENVIRONMENT, which contribute $70 \%$ of all the articles in WoS and which future studies could aim for. In addition, the network of cluster terms closely associated with the topics of CE \& DE are Sustainability, I4.0, Design, Management, and Framework, which future studies could set upon. Further, hot research keywords of the CE \& DE via overlay visualization in last five years, 2016 to 2020, indicates five major schemes, namely, collaborative working method, economy, emerging information-technology, initiative, and waste associated sustainability, which future studies could consider. However, there are research gaps in a large number of subject areas in multidisciplinary research. The implementation of relevant strategies across products' life cycle stages has great potential to promote the CE, while the most current studies focus on the End-of-Life Cycle stage. Accelerating the integration and innovation of digital technology with other areas can trigger multi-sphere, multi-dimensional breakthroughs. The main limitation of this study is that only one database, WoS, is used. Some related publications may be indexed by other databases, rather than in the WoS. Future follow-up studies may consider exploring a method using data from different databases, such as Scopus, that are currently hard to directly connect with and visualize via the VOSviewer, to compare the results reported in this study.

Author Contributions: Conceptualization, Z.L. and J.L.; Methodology, Z.L., J.L. and M.O.; Software, J.L.; Validation, Z.L., J.L. and M.O.; Formal analysis, J.L.; Investigation, Z.L. and J.L.; Resources, Z.L.; Data curation, Z.L. and J.L.; Writing—original draft preparation, Z.L. and J.L.; Writing-review and editing, Z.L., J.L. and M.O.; Visualization, J.L.; Supervision, Z.L.; Project administration, Z.L.; Funding acquisition, Z.L. All authors have read and agreed to the published version of the manuscript. 
Funding: This research was funded by Guangdong Provincial Department of Science and Technology 2020-2021 Overseas Famous Teacher Project: grant number 2020A1414010178, Guangzhou City Philosophy and Social Science Planning 2020 Annual Project: grant number 2020GZYB12, and South China University of Technology Central University Basic Scientific Research Operation Funds (Social Science): (x2sjC2191370) grant number XYZD201928.

Institutional Review Board Statement: Not applicable.

Informed Consent Statement: Not applicable.

Data Availability Statement: Publicly available datasets were analyzed in this study. This data can be found here: [https://login.webofknowledge.com].

Acknowledgments: The authors wish to thank all the people who support this research and three anonymous reviewers for their valuable comments, which have greatly improved this paper. Z.L. would like to thank one-year Isabella for her inspiration, courage and hope during this COVID19 epidemic since 2020, which is the same with current Digital Economy to Circular Economy. Particularly, J.L. would like to thank her family and friends for their encouragements and supports, and Netease CloudMusic for accompanying and healing her, and her supervisor and the School of Design, South China University of Technology, for providing her academic direction and environment during the study.

Conflicts of Interest: The authors declare that there are no conflicts of interest.

\section{References}

1. Murray, A.; Skene, K.; Haynes, K. The Circular Economy: An Interdisciplinary Exploration of the Concept and Application in a Global Context. J. Bus. Ethics 2017, 140, 369-380. [CrossRef]

2. Greyson, J. An economic instrument for zero waste, economic growth and sustainability. J. Clean. Prod. 2007, 15, 1382-1390. [CrossRef]

3. Boulding, K.E. The Economics of the Coming Spaceship Earth. Environmental Ouality in a Growing Economy; Jarrett, H., Ed.; Resources for the Future/Johns Hopkins University Press: Baltimore, MD, USA, 1966.

4. Liu, Q.; Li, H.; Zuo, X.; Zhang, F.; Wang, L. A survey and analysis on public awareness and performance for promoting circular economy in China: A case study from Tianjin. J. Clean. Prod. 2009, 17, 265-270. [CrossRef]

5. Yuan, Z.W.; Bi, J.; Moriguichi, Y. The circular economy-A new development strategy in China. J. Ind. Ecol. 2006, 10, 4-8. [CrossRef]

6. Pearce, D.; Turner, R.K. Economics of natural resources and the environment, Hemel Hempstead: Harvester Wheatsheaf. In Natural Resource and Environmental Economics, 3rd ed.; Perman, R., Ma, Y., McGilvray, J., Common, M., Eds.; Johns Hopkins University Press: Baltimore, MD, USA, 1990.

7. Korhonen, J.; Honkasalo, A.; Seppala, J. Circular Economy: The Concept and its Limitations. Ecol. Econ. 2018, 143, 37-46. [CrossRef]

8. EMAF, E.M.F. Towards the Circular Economy-Economic and Business Rationale for an Accelerated Transition; EMAF: Cowes, UK, 2012.

9. Jabbour, C.J.C.; Jabbour, A.B.L.D.; Sarkis, J.; Godinho Filho, M. Unlocking the circular economy through new business models based on large-scale data: An integrative framework and research agenda. Technol. Forecast. Soc. 2019, 144, 546-552. [CrossRef]

10. Nobre, G.C.; Tavares, E. Scientific literature analysis on big data and internet of things applications on circular economy: A bibliometric study. Scientometrics 2017, 111, 463-492. [CrossRef]

11. EMF, E.M.F. Towards the Circular Economy: Accelerating the Scale-Up across Global Supply Chains; Ellen MacArthur Foundation (EMF): Isle of Wight, UK, 2014.

12. EY. Are You Ready for the Circular Economy? The Necessity of an Integrated Approach. 2015. Available online: http: / / www.ey.com/Publication/vwLUAssets/EY-brochure-cas-are-you-ready-for-the-circular-economy/\$FILE/EYbrochure-cas-are-you-ready-for-the-circular-economy.pdf (accessed on 5 September 2017).

13. Kirchherr, J.; Reike, D.; Hekkert, M. Conceptualizing the circular economy: An analysis of 114 definitions. Resour. Conserv. Recy. 2017, 127, 221-232. [CrossRef]

14. Neely, A. Exploring the financial consequences of the servitization of manufacturing. Oper. Manag. Res. 2008, 1, 103-118. [CrossRef]

15. Tukker, A. Product services for a resource-efficient and circular economy-a review. J. Clean. Prod. 2015, 97, 76-91. [CrossRef]

16. Bezerra Barquet, A.P.; de Oliveira, M.G.; Amigo, C.R.; Cunha, V.P.; Rozenfeld, H. Employing the business model concept to support the adoption of product-service systems (PSS). Ind. Market. Manag. 2013, 42, 693-704. [CrossRef]

17. Rizos, V.; Behrens, A.; Van der Gaast, W.; Hofman, E.; Ioannou, A.; Kafyeke, T.; Flamos, A.; Rinaldi, R.; Papadelis, S.; HirschnitzGarbers, M. Implementation of circular economy business models by small and medium-sized enterprises (SMEs): Barriers and enablers. Sustainability 2016, 8, 1212. [CrossRef] 
18. Linder, M.; Williander, M. Circular business model innovation: Inherent uncertainties. Bus. Strategy Environ. 2017, 26, 182-196. [CrossRef]

19. Franco, M.A. Circular economy at the micro level: A dynamic view of incumbents' struggles and challenges in the textile industry. J. Clean. Prod. 2017, 168, 833-845. [CrossRef]

20. Bressanelli, G.; Adrodegari, F.; Perona, M.; Saccani, N. The role of digital technologies to overcome Circular Economy challenges in PSS Business Models: An exploratory case study. In Procedia CIRP; Sakao, T., Lindahl, M., Liu, Y., Dalhammar, C., Eds.; Elsevier Science BV: Amsterdam, The Netherlands, 2018; Volume 73, pp. 216-221.

21. D'Adamo, I.; Lupi, G. Sustainability and Resilience after COVID-19: A Circular Premium in the Fashion Industry. Sustainability 2021, 13, 1861. [CrossRef]

22. Morlet, A.; Blériot, J.; Opsomer, R.; Linder, M.; Henggeler, A.; Bluhm, A.; Carrera, A. Intelligent Assets: Unlocking the Circular Economy Potential; Ellen MacArthur Foundation: Cowes, UK, 2016; pp. 1-25.

23. Bressanelli, G.; Adrodegari, F.; Perona, M.; Saccani, N. Exploring How Usage-Focused Business Models Enable Circular Economy through Digital Technologies. Sustainability 2018, 10, 639. [CrossRef]

24. Sturgeon, T.J. Upgrading strategies for the digital economy. Glob. Strategy J. 2021, 11, 34-57. [CrossRef]

25. Gereffi, G.; Humphrey, J.; Sturgeon, T. The Governance of global value chains. Rev. Int. Political Econ. 2005, 12, 78-104. [CrossRef]

26. Zhen, Z.; Yousaf, Z.; Radulescu, M.; Yasir, M. Nexus of Digital Organizational Culture, Capabilities, Organizational Readiness, and Innovation: Investigation of SMEs Operating in the Digital Economy. Sustainability 2021, 13, 720. [CrossRef]

27. Pimenova, E.M. Specificity of Sustainability Assessment for Industrial Enterprise Functioning in the Digital Economy; Ashmarina, S.I., Mantulenko, V.V., Vochozka, M., Eds.; Springer International Publishing: Cham, Switzerland, 2021; pp. 3-10.

28. Despeisse, M.; Baumers, M.; Brown, P.; Charnley, F.; Ford, S.J.; Garmulewicz, A.; Knowles, S.; Minshall, T.H.W.; Mortara, L.; Reed-Tsochas, F.P.; et al. Unlocking value for a circular economy through 3D printing: A research agenda. Technol. Forecast. Soc. 2017, 115, 75-84. [CrossRef]

29. Pagoropoulos, A.; Pigosso, D.; McAloone, T.C. The emergent role of digital technologies in the Circular Economy: A review. In Procedia CIRP; McAloone, T.C., Pigosso, D., Mortensen, N.H., Shimomura, Y., Eds.; Elsevier Science BV: Amsterdam, The Netherlands, 2017; Volume 64, pp. 19-24.

30. Bressanelli, G.; Perona, M.; Saccani, N. Reshaping the Washing Machine Industry through Circular Economy and Product-Service System Business Models. In Procedia CIRP; McAloone, T.C., Pigosso, D., Mortensen, N.H., Shimomura, Y., Eds.; Elsevier Science BV: Amsterdam, The Netherlands, 2017; Volume 64, pp. 43-48.

31. Baines, T.; Lightfoot, H.W. Servitization of the manufacturing firm Exploring the operations practices and technologies that deliver advanced services. Int. J. Oper. Prod. Manag. 2014, 34, 2-35. [CrossRef]

32. Lewandowski, M. Designing the Business Models for Circular Economy-Towards the Conceptual Framework. Sustainability 2016, 8, 43. [CrossRef]

33. Pialot, O.; Millet, D.; Bisiaux, J. "Upgradable PSS": Clarifying a new concept of sustainable consumption/production based on upgradablility. J. Clean. Prod. 2017, 141, 538-550. [CrossRef]

34. UGLI, R.D.J.; UGLI, K.A.M. The Concept of Digital Economy in Modern Life and Its Application to Life. JournalNX 2020, 6, $118-121$.

35. Ibn-Mohammed, T.; Mustapha, K.B.; Godsell, J.; Adamu, Z.; Babatunde, K.A.; Akintade, D.D.; Acquaye, A.; Fujii, H.; Ndiaye, M.M.; Yamoah, F.A.; et al. A critical analysis of the impacts of COVID-19 on the global economy and ecosystems and opportunities for circular economy strategies. Resour. Conserv. Recy. 2021, 164, 105169. [CrossRef] [PubMed]

36. Liu, D. Interpretation of New Prospects of the Global Digital Economy (2020)—New Driving Forces for Sustainable Development in the Changing Era. Internet World 2020, 8-15. Available online: https: / /kns.cnki.net $/ \mathrm{kcms} /$ detail $/$ detail.aspx?FileName= HLWT202010003\&DbName=CJFQ2020 (accessed on 8 February 2021).

37. Naidoo, R.; Fisher, B. Reset Sustainable Development Goals for a Pandemic World; Nature Publishing Group: Berlin, Germany, 2020.

38. Ghisellini, P.; Cialani, C.; Ulgiati, S. A review on circular economy: The expected transition to a balanced interplay of environmental and economic systems. J. Clean. Prod. 2016, 114, 11-32. [CrossRef]

39. Miehe, R.; Fischer, E.; Berndt, D.; Herzog, A.; Horbelt, J.; Full, J.; Bauernhansl, T.; Schenk, M. Enabling Bidirectional Real Time Interaction between Biological and Technical Systems: Structural Basics of a Control Oriented Modeling of Biology-Technology-Interfaces; Butala, P., Govekar, E., Vrabic, R., Eds.; Elsevier: Amsterdam, The Netherlands, 2019; Volume 81, pp. $63-68$.

40. Damar, H.T.; Bilik, O.; Ozdagoglu, G.; Ozdagoglu, A.; Damar, M. Scientometric overview of nursing research on pain management. Rev. Lat. Am. Enferm. 2018, 26, e3051. [CrossRef]

41. Van Eck, N.J.; Waltman, L. Software survey: VOSviewer, a computer program for bibliometric mapping. Scientometrics 2010, 84, 523-538. [CrossRef] [PubMed]

42. Devos, P.; Menard, J. Trends in Worldwide Research in Hypertension over the Period 1999-2018 A Bibliometric Study. Hypertension 2020, 76, 1649-1655. [CrossRef]

43. Yeung, A.W.K.; Tzvetkov, N.T.; Durazzo, A.; Lucarini, M.; Souto, E.B.; Santini, A.; Gan, R.; Jozwik, A.; Grzybek, W.; Horbanczuk, J.O.; et al. Natural products in diabetes research: Quantitative literature analysis. Nat. Prod. Res. 2020. [CrossRef]

44. Fu, J.; Jiang, Z.; Hong, Y.; Liu, S.; Kong, D.; Zhong, Z.; Luo, Y. Global scientific research on social participation of older people from 2000 to 2019: A bibliometric analysis. Int. J. Older People N 2021, 16, e12349. [CrossRef] 
45. Feng, Y.; Cui, S. A review of emergency response in disasters: Present and future perspectives. Nat. Hazards 2021, 105, 1109-1138. [CrossRef]

46. Chen, C.; Dubin, R.; Kim, M.C. Emerging trends and new developments in regenerative medicine: A scientometric update (2000-2014). Expert Opin. Biol. Ther. 2014, 14, 1295-1317. [CrossRef]

47. Huang, L.; Chen, K.; Zhou, M. Climate change and carbon sink: A bibliometric analysis. Environ. Sci. Pollut. R 2020, 27, 8740-8758. [CrossRef]

48. Li, H.; An, H.; Wang, Y.; Huang, J.; Gao, X. Evolutionary features of academic articles co-keyword network and keywords co-occurrence network: Based on two-mode affiliation network. Phys. A 2016, 450, 657-669. [CrossRef]

49. Van Eck, N.J.; Waltman, L. Citation-based clustering of publications using CitNetExplorer and VOSviewer. Scientometrics 2017, 111, 1053-1070. [CrossRef]

50. Abdul-Hamid, A.; Ali, M.H.; Tseng, M.; Lan, S.; Kumar, M. Impeding challenges on industry 4.0 in circular economy: Palm oil industry in Malaysia. Comput. Oper. Res. 2020, 123, 105052. [CrossRef]

51. Garrido-Hidalgo, C.; Javier Ramirez, F.; Olivares, T.; Roda-Sanchez, L. The adoption of internet of things in a circular supply chain framework for the recovery of WEEE: The case of lithium-ion electric vehicle battery packs. Waste Manag. 2020, 103, 32-44. [CrossRef] [PubMed]

52. Tunn, V.S.C.; van den Hende, E.A.; Bocken, N.M.P.; Schoormans, J.P.L. Digitalised product-service systems: Effects on consumers' attitudes and experiences. Resour. Conserv. Recy. 2020, 162, 105045. [CrossRef]

53. Moreno, M.; Turner, C.; Tiwari, A.; Hutabarat, W.; Charnley, F.; Widjaja, D.; Mondini, L. Re-Distributed Manufacturing to Achieve a Circular Economy: A Case Study Utilizing IDEF0 Modeling; Tseng, M.M., Tsai, H.Y., Wang, Y., Eds.; Elsevier Science BV: Amsterdam, The Netherlands, 2017; Volume 63, pp. 686-691.

54. Zhong, S.; Pearce, J.M. Tightening the loop on the circular economy: Coupled distributed recycling and manufacturing with recyclebot and RepRap 3-D printing. Resour. Conserv. Recy. 2018, 128, 48-58. [CrossRef]

55. Bag, S.; Dhamija, P.; Gupta, S.; Sivarajah, U. Examining the role of procurement 4.0 towards remanufacturing operations and circular economy. Prod. Plan. Control 2020. [CrossRef]

56. Sarc, R.; Curtis, A.; Kandlbauer, L.; Khodier, K.; Lorber, K.E.; Pomberger, R. Digitalisation and intelligent robotics in value chain of circular economy oriented waste management-A review. Waste Manag. 2019, 95, 476-492. [CrossRef]

57. Byard, D.J.; Woern, A.L.; Oakley, R.B.; Fiedler, M.J.; Snabes, S.L.; Pearce, J.M. Green fab lab applications of large-area waste polymer-based additive manufacturing. Addit. Manuf. 2019, 27, 515-525. [CrossRef]

58. Charles, R.G.; Douglas, P.; Dowling, M.; Liversage, G.; Davies, M.L. Towards Increased Recovery of Critical Raw Materials from WEEE-evaluation of CRMs at a component level and pre-processing methods for interface optimisation with recovery processes. Resour. Conserv. Recy. 2020, 161, 104923. [CrossRef]

59. Botleng, V.; Brunel, S.; Girard, P. Providing a Conducive Environment to Integrate Design and Production: Assessing the Potentials of University-Based Fablabs (Ub-Fablabs). In International Conference on Engineering Design; Maier, A., Skec, S., Kim, H., Kokkolaras, M., Oehmen, J., Fadel, G., Salustri, F., VanDerLoos, M., Eds.; Design Soc: Glasgow, UK, 2017 ; pp. 11-20.

60. Antikainen, M.; Uusitalo, T.; Kivikyto-Reponen, P. Digitalisation as an Enabler of Circular Economy. In Procedia CIRP; Sakao, T., Lindahl, M., Liu, Y., Dalhammar, C., Eds.; Elsevier Science Bv: Amsterdam, The Netherlands, 2018; Volume 73, pp. 45-49.

61. Ghobakhloo, M. Industry 4.0, digitization, and opportunities for sustainability. J. Clean. Prod. 2020, 252, 119869. [CrossRef]

62. Kerin, M.; Pham, D.T. Smart remanufacturing: A review and research framework. J. Manuf. Technol. Manag. 2020, 31, 1205-1235. [CrossRef]

63. Kerin, M.; Duc Truong, P. A review of emerging industry 4.0 technologies in remanufacturing. J. Clean. Prod. 2019, $237,117805$. [CrossRef]

64. Rosa, P.; Sassanelli, C.; Urbinati, A.; Chiaroni, D.; Terzi, S. Assessing relations between Circular Economy and Industry 4.0: A systematic literature review. Int. J. Prod. Res. 2020, 58, 1662-1687. [CrossRef]

65. Sartal, A.; Bellas, R.; Mejias, A.M.; Garcia-Collado, A. The sustainable manufacturing concept, evolution and opportunities within Industry 4.0: A literature review. Adv. Mech. Eng. 2020, 12. [CrossRef]

66. Rajput, S.; Singh, S.P. Industry 4.0 Model for circular economy and cleaner production. J. Clean. Prod. 2020, 277, 123853. [CrossRef]

67. Martin-Gomez, A.; Aguayo-Gonzalez, F.; Luque, A. A holonic framework for managing the sustainable supply chain in emerging economies with smart connected metabolism. Resour. Conserv. Recy. 2019, 141, 219-232. [CrossRef]

68. Schwanholz, J.; Leipold, S. Sharing for a circular economy? An analysis of digital sharing platforms' principles and business models. J. Clean. Prod. 2020, 269, 122327. [CrossRef]

69. Cioffi, R.; Travaglioni, M.; Piscitelli, G.; Petrillo, A.; Parmentola, A. Smart Manufacturing Systems and Applied Industrial Technologies for a Sustainable Industry: A Systematic Literature Review. Appl. Sci. 2020, 10, 2897. [CrossRef]

70. Ertz, M.; Leblanc-Proulx, S.; Sarigollu, E.; Morin, V. Made to break? A taxonomy of business models on product lifetime extension. J. Clean. Prod. 2019, 234, 867-880. [CrossRef]

71. Avila-Gutierrez, M.J.; Martin-Gomez, A.; Aguayo-Gonzalez, F.; Cordoba-Roldan, A. Standardization Framework for Sustainability from Circular Economy 4.0. Sustainability 2019, 11, 6490. [CrossRef]

72. Rocca, R.; Rosa, P.; Sassanelli, C.; Fumagalli, L.; Terzi, S. Integrating Virtual Reality and Digital Twin in Circular Economy Practices: A Laboratory Application Case. Sustainability 2020, 12, 2286. [CrossRef] 
73. Rossi, J.; Bianchini, A.; Guarnieri, P. Circular Economy Model Enhanced by Intelligent Assets from Industry 4.0: The Proposition of an Innovative Tool to Analyze Case Studies. Sustainability 2020, 12, 7147. [CrossRef]

74. Revinova, S.; Ratner, S.; Lazanyuk, I.; Gomonov, K. Sharing Economy in Russia: Current Status, Barriers, Prospects and Role of Universities. Sustainability 2020, 12, 4855. [CrossRef]

75. Scavarda, A.; Dau, G.; Scavarda, L.F.; Azevedo, B.D.; Korzenowski, A.L. Social and ecological approaches in urban interfaces: A sharing economy management framework. Sci. Total Environ. 2020, 713, 134407. [CrossRef]

76. Kasulaitis, B.; Babbitt, C.W.; Tyler, A.C. The role of consumer preferences in reducing material intensity of electronic products. J. Ind. Ecol. 2020. [CrossRef]

77. Halverson, E.R.; Sheridan, K.M. The Maker Movement in Education. Harvard Educ. Rev. 2014, 84, 495-504. [CrossRef]

78. Gan, V.J.L.; Lo, I.M.C.; Ma, J.; Tse, K.T.; Cheng, J.C.P.; Chan, C.M. Simulation optimisation towards energy efficient green buildings: Current status and future trends. J. Clean. Prod. 2020, 254, 120012. [CrossRef]

79. Hao, J.L.; Cheng, B.; Lu, W.; Xu, J.; Wang, J.; Bu, W.; Guo, Z. Carbon emission reduction in prefabrication construction during materialization stage: A BIM-based life-cycle assessment approach. Sci. Total Environ. 2020, 723, 137870. [CrossRef]

80. Millard, J.; Sorivelle, M.N.; Deljanin, S.; Unterfrauner, E.; Voigt, C. Is the Maker Movement Contributing to Sustainability? Sustainability 2018, 10, 2212. [CrossRef]

81. Unterfrauner, E.; Shao, J.; Hofer, M.; Fabian, C.M. The environmental value and impact of the Maker movement-Insights from a cross-case analysis of European maker initiatives. Bus. Strategy Environ. 2019, 28, 1518-1533. [CrossRef]

82. Ingemarsdotter, E.; Jamsin, E.; Kortuem, G.; Balkenende, R. Circular Strategies Enabled by the Internet of Things-A Framework and Analysis of Current Practice. Sustainability 2019, 11, 5689. [CrossRef]

83. Charnley, F.; Tiwari, D.; Hutabarat, W.; Moreno, M.; Okorie, O.; Tiwari, A. Simulation to Enable a Data-Driven Circular Economy. Sustainability 2019, 11, 3379. [CrossRef]

84. Chen, X.; Despeisse, M.; Johansson, B. Environmental Sustainability of Digitalization in Manufacturing: A Review. Sustainability 2020, 12, 10298. [CrossRef]

85. Franquesa, D.; Navarro, L. Devices as a Commons: Limits to Premature Recycling; ASSOC Computing Machinery: New York, NY, USA, 2018.

86. Townsend, J.H.; Coroama, V.C. Digital Acceleration of Sustainability Transition: The Paradox of Push Impacts. Sustainability 2018, 10, 2816. [CrossRef]

87. Ma, S.; Zhang, Y.; Liu, Y.; Yang, H.; Lv, J.; Ren, S. Data-driven sustainable intelligent manufacturing based on demand response for energy-intensive industries. J. Clean. Prod. 2020, 274, 123155. [CrossRef]

88. Matt, C.; Hess, T.; Benlian, A. Digital Transformation Strategies. Bus. Inf. Syst. Eng. 2015, 57, 339-343. [CrossRef]

89. Zheng, P.; Wang, Z.; Chen, C.; Khoo, L.P. A survey of smart product-service systems: Key aspects, challenges and future perspectives. Adv. Eng. Inf. 2019, 42, 100973. [CrossRef]

90. Mikalef, P.; Pappas, I.O.; Krogstie, J.; Pavlou, P.A. Big data and business analytics: A research agenda for realizing business value. Inf. Manag. 2020, 57, 103237. [CrossRef]

91. Hoosain, M.S.; Paul, B.S.; Ramakrishna, S. The Impact of 4IR Digital Technologies and Circular Thinking on the United Nations Sustainable Development Goals. Sustainability 2020, 12, 10143. [CrossRef]

92. Sauerwein, M.; Bakker, C.A.; Balkenende, A.R. Additive Manufacturing for Circular Product Design: A Literature Review from a Design Perspective; Bakker, C., Mugge, R., Eds.; IOS Press: Amsterdam, The Netherlands, 2017; pp. 358-364.

93. Floren, H.; Barth, H.; Gullbrand, J.; Holmen, M. Additive manufacturing technologies and business models-A systematic literature review. J. Manuf. Technol. Manag. 2021, 32, 136-155. [CrossRef]

94. Vehmas, K.; Raudaskoski, A.; Heikkilae, P.; Harlin, A.; Mensonen, A. Consumer attitudes and communication in circular fashion. J. Fash. Mark. Manag. 2018, 22, 286-300. [CrossRef]

95. Sandvik, I.M.; Stubbs, W. Circular fashion supply chain through textile-to-textile recycling. J. Fash. Mark. Manag. 2019, 23, 366-381. [CrossRef]

96. Rajala, R.; Hakanen, E.; Mattila, J.; Seppala, T.; Westerlund, M. How Do Intelligent Goods Shape Closed-Loop Systems? Calif. Manag. Rev. 2018, 60, 20-44. [CrossRef]

97. Moennig, A.; Maier, T.; Zika, G. Economy 4.0-Digitalisation and Its Effect on Wage Inequality. Jahrb. Natl. Stat. 2019, 239, 363-398. [CrossRef]

98. Woern, A.L.; Byard, D.J.; Oakley, R.B.; Fiedler, M.J.; Snabes, S.L.; Pearce, J.M. Fused Particle Fabrication 3-D Printing: Recycled Materials' Optimization and Mechanical Properties. Materials 2018, 11, 1413. [CrossRef]

99. Bag, S.; Wood, L.C.; Mangla, S.K.; Luthra, S. Procurement 4.0 and its implications on business process performance in a circular economy. Resour. Conserv. Recy. 2020, 152, 104502. [CrossRef]

100. Melkonyan, A.; Gruchmann, T.; Lohmar, F.; Kamath, V.; Spinler, S. Sustainability assessment of last-mile logistics and distribution strategies: The case of local food networks. Int. J. Prod. Econ. 2020, 228, 107746. [CrossRef]

101. Kunovjanek, M.; Knofius, N.; Reiner, G. Additive manufacturing and supply chains-A systematic review. Prod. Plan. Control 2020. [CrossRef]

102. Prendeville, S.; Hartung, G.; Purvis, E.; Brass, C.; Hall, A. Makespaces: From Redistributed Manufacturing to a Circular Economy. In Smart Innovation Systems and Technologies; Setchi, R., Howlett, R.J., Liu, Y., Theobald, P., Eds.; Springer: Berlin/Heidelberg, Germany, 2016; Volume 52, pp. 577-588. 
103. Kusiak, A. Fundamentals of smart manufacturing: A multi-thread perspective. Annu. Rev. Control 2019, 47, 214-220. [CrossRef]

104. Fisher, O.J.; Watson, N.J.; Escrig, J.E.; Gomes, R.L. Intelligent Resource Use to Deliver Waste Valorisation and Process Resilience in Manufacturing Environments Moving towards sustainable process manufacturing. Johnson Matthey Tech. 2020, 64, 93-99. [CrossRef]

105. Schischke, K.; Manessis, D.; Pawlikowski, J.; Kupka, T.; Krivec, T.; Pamminger, R.; Glaser, S.; Podhradsky, G.; Nissen, N.F.; Schneider-Ramelow, M.; et al. Embedding as a key Board-Level Technology for Modularization and Circular Design of Smart Mobile Products: Environmental Assessment. In European Microelectronics Packaging Conference; IEEE: New York, NY, USA, 2019.

106. Gonzalez-Varona, J.M.; Poza, D.; Acebes, F.; Villafanez, F.; Pajares, J.; Lopez-Paredes, A. New Business Models for Sustainable Spare Parts Logistics: A Case Study. Sustainability 2020, 12, 3071. [CrossRef]

107. Tomiyama, T.; Lutters, E.; Stark, R.; Abramovici, M. Development capabilities for smart products. CIRP Ann. Manuf. Technol. 2019, 68, 727-750. [CrossRef]

108. Bertin, I.; Lebrun, F.; Braham, N.; Le Roy, R. Construction, deconstruction, reuse of the structural elements: The circular economy to reach zero carbon. In IOP Conference Series-Earth and Environmental Science; Passer, A., Lutzkendorf, T., Habert, G., KrompKolb, H., Monsberger, M., Eds.; Iop Publishing Ltd.: Bristol, UK, 2019; Volume 323.

109. Bausys, R.; Cavallaro, F.; Semenas, R. Application of Sustainability Principles for Harsh Environment Exploration by Autonomous Robot. Sustainability 2019, 11, 2518. [CrossRef]

110. Watanabe, C.; Naveed, N.; Neittaanmaki, P. Digitalized bioeconomy: Planned obsolescence-driven circular economy enabled by Co-Evolutionary coupling. Technol. Soc. 2019, 56, 8-30. [CrossRef]

111. Nogueira, A.; Ashton, W.S.; Teixeira, C. Expanding perceptions of the circular economy through design: Eight capitals as innovation lenses. Resour. Conserv. Recy. 2019, 149, 566-576. [CrossRef]

112. El Hilali, W.; El Manouar, A. Towards a Sustainable World through a Smart Digital Transformation; Assoc Computing Machinery: New York, NY, USA, 2019.

113. Eden, S. Blurring the boundaries: Prosumption, circularity and online sustainable consumption through Freecycle. J. Consum. Cult. 2017, 17, 265-285. [CrossRef]

114. Okorie, O.; Turner, C.; Salonitis, K.; Charnley, F.; Moreno, M.; Tiwari, A.; Hutabarat, W. A Decision-Making Framework for the Implementation of Remanufacturing in Rechargeable Energy Storage System in Hybrid and Electric Vehicles. In Procedia Manufacturing; Onori, M., Wang, L., Wang, X.V., Ji, W., Eds.; Elsevier Science BV: Amsterdam, The Netherlands, 2018; Volume 25, pp. 142-153.

115. Sitek, J.; Koscielski, M.; Arazna, A.; Janeczek, K.; Steplewski, W. Investigations of BGA Components' Balls Remanufacturing Techniques for Circular Economy Applications; IEEE: New York, NY, USA, 2018.

116. Pamminger, R.; Kuso, D.; Wimmer, W.; Podhardsky, G. Re-Design of a Digital Voice Recorder to Meet the Needs of Circular Economy Status Analysis; IEEE: New York, NY, USA, 2016.

117. Makarova, I.; Andreev, A.; Gubacheva, L.; Shevchenko, D. Industry 4.0 in production and household waste processing. In International Conference on Developments in eSystems Engineering; AlJumeily, D., Hind, J., Mustafina, J., AlHajj, A., Hussain, A., Magid, E., Tawfik, H., Eds.; IEEE: New York, NY, USA, 2019; pp. 794-799.

118. Tuzun, U. Artificial Intelligence Assisted Dynamic Control of Environmental Emissions from Hybrid Energy Process Plants (HEPP). Front. Energy Res. 2020, 8. [CrossRef]

119. Llamas, A.; Bartie, N.J.; Heibeck, M.; Stelter, M.; Reuter, M.A. Simulation-Based Exergy Analysis of Large Circular Economy Systems: Zinc Production Coupled to CdTe Photovoltaic Module Life Cycle. J. Sustain. Metall. 2020, 6, 34-67. [CrossRef]

120. Vonk, L. Paying attention to waste: Apple's circular economy. Contin.-J. Media Cult. Stud. 2018, 32, 745-757. [CrossRef]

121. Dounavis, A.S.; Kafasis, P.; Ntavos, N. Using an online platform for the improvement of industrial symbiosis and circular economy (in Western Macedonia, Greece). Glob. Nest J. 2019, 21, 76-81.

122. Matschewsky, J. Unintended Circularity?Assessing a Product-Service System for its Potential Contribution to a Circular Economy. Sustainability 2019, 11, 2725. [CrossRef]

123. Succar, B.; Poirier, E. Lifecycle information transformation and exchange for delivering and managing digital and physical assets. Automat. Constr. 2020, 112, 103090. [CrossRef]

124. Jesus Avila-Gutierrez, M.; Martin-Gomez, A.; Aguayo-Gonzalez, F.; Ramon Lama-Ruiz, J. Eco-Holonic 4.0 Circular Business Model to Conceptualize Sustainable Value Chain towards Digital Transition. Sustainability 2020, 12, 1889. [CrossRef]

125. Kunkel, S.; Matthess, M. Digital transformation and environmental sustainability in industry: Putting expectations in Asian and African policies into perspective. Environ. Sci. Policy 2020, 112, 318-329. [CrossRef]

126. Margherita, E.G.; Braccini, A.M. Industry 4.0 Technologies in Flexible Manufacturing for Sustainable Organizational Value: Reflections from a Multiple Case Study of Italian Manufacturers. Inf. Syst. Front. 2020. [CrossRef]

127. Zheng, P.; Wang, Z.X.; Chen, C.H. Smart Product-Service Systems: A Novel Transdisciplinary Sociotechnical Paradigm. In Advances in Transdisciplinary Engineering; Hiekata, K., Moser, B., Inoue, M., Stjepandic, J., Wognum, N., Eds.; IOS Press: Amsterdam, The Netherlands, 2019; Volume 10, pp. 234-241.

128. Romero, D.; Noran, O. Towards Green Sensing Virtual Enterprises: Interconnected Sensing Enterprises, Intelligent Assets and Smart Products in the Cyber-Physical Circular Economy. IFAC Pap. 2017, 50, 11719-11724. [CrossRef]

129. Lekan, M.; Rogers, H.A. Digitally enabled diverse economies: Exploring socially inclusive access to the circular economy in the city. Urban Geogr. 2020, 41, 898-901. [CrossRef] 
130. Zavratnik, V.; Superina, A.; Duh, E.S. Living Labs for Rural Areas: Contextualization of Living Lab Frameworks, Concepts and Practices. Sustainability 2019, 11, 3797. [CrossRef]

131. Kalmykova, Y.; Sadagopan, M.; Rosado, L. Circular economy-From review of theories and practices to development of implementation tools. Resour. Conserv. Recy. 2018, 135, 190-201. [CrossRef]

132. Koenig, B.; Diehl, K.; Tscherning, K.; Helming, K. A framework for structuring interdisciplinary research management. Res. Policy 2013, 42, 261-272. [CrossRef]

133. Sheng, J.; Amankwah-Amoah, J.; Wang, X. A multidisciplinary perspective of big data in management research. Int. J. Prod. Econ. 2017, 191, 97-112. [CrossRef]

134. Lopez-Benitez, M.; Drysdale, T.D.; Hadfield, S.; Maricar, M.I. Prototype for multidisciplinary research in the context of the Internet of Things. J. Netw. Comput Appl. 2017, 78, 146-161. [CrossRef]

135. Akimov, S.S. Business process modeling within the digital economy development framework. In AEBMR-Advances in Economics Business and Management Research; Nazarov, A., Ed.; Atlantis Press: Paris, France, 2019; Volume 81, pp. $262-267$.

136. Andronova, I.V.; Belova, I.N.; Yakimovich, E.A. Digital technology in the fishing sector: International and Russian experience. In AEBMR-Advances in Economics Business and Management Research; Nazarov, A., Ed.; Atlantis Press: Paris, France, 2019; Volume 81, pp. 277-280.

137. Yan, D.L. Comparative study on the gap between Chinese and American digital economy. Internet World 2020, 22-27. Available online: https:/ / kns.cnki.net/kcms/detail/detail.aspx?FileName=HLWT202010005\&DbName=CJFQ2020 (accessed on 8 February 2021). 